\title{
Obiteljski odnosi i roditeljstvo u obiteljima različitog prihoda: kako je život u visokom riziku od siromaštva povezan $s$ funkcioniranjem obitelji adolescenata?*
}

\author{
MARINA AJDUKOVIĆ ${ }^{* *}$ \\ Studijski centar socijalnog rada \\ Pravni fakultet Sveučilišta u Zagrebu \\ Zagreb, Hrvatska
}

\author{
MIROSLAV RAJTER \\ Ured za istraživanje \\ Sveučilište u Zagrebu \\ Zagreb, Hrvatska
}

\section{INES REZO}

Studijski centar socijalnog rada

Pravni fakultet Sveučilišta u Zagrebu

Zagreb, Hrvatska

\author{
Izvorni znanstveni rad \\ UDK: 364.65-058.34:37.018-053.6 \\ doi: 10.3935/rsp.v26i1.1602 \\ Primljeno: rujan 2018.
}

U radu se prikazuje doprinos objektivnih i subjektivnih pokazatelja socioekonomskog statusa, izloženosti stresnim događajima i dostupnosti socijalne podrške kvaliteti obiteljskih odnosa i riziku za zlostavljanje djece kod majki adolescenata u obiteljima izloženim visokom i niskom riziku od siromaštva. U istraživanju su sudjelovale 392 majke čija su djeca učenici prvih razreda srednjih škola. Kriterij za klasifikaciju obitelji u one s visokim (VRS) i niskim rizikom od siromaštva (NRS) usklađen je s cenzusom za primanja većeg doplatka za djecu $(N=163$, VRS, prosječni prihod po članu domaćinstva 719,14 kuna) u odnosu na obitelji koje nemaju pravo na dječji doplatak $(N=229, N R S$, prosječni prihod po članu domaćinstva 3 357,53 kuna). Rezultati su pokazali da, u skladu s Congerovim modelom obiteljskog stresa, u obiteljima koje su u visokom riziku od siromaštva konflikti u obitelji (mjereno Skalom obiteljskog funkcioniranja; Noller, 1988.) i rizik majki za zlostavljanje djece (mjereno Inventarom rizičnost za zlostavljanje djece; Milner, 1986.) statistički su značajno češći u odnosu na obitelji koje su u niskom riziku. Kod majki VRS značajni prediktori rizičnosti za zlostavljanje djece su posramljenost zbog financijske situacije i izloženost većem broju stresnih događaja. Kod majki VRS, socijalna podrška, iako značajno smanjuje rizik od zlostavljanja djece, ima vidljivo

\footnotetext{
* Ovaj rad financirala je Hrvatska zaklada za znanost projektom »Ekonomske teškoće obitelji, psihosocijalni problemi i obrazovni ishodi adolescenata u vrijeme ekonomske krize« [IP-2014-09-8546].

** Marina Ajduković, Studijski centar socijalnog rada, Pravni fakultet Sveučilišta u Zagrebu / Department of Social Work, Faculty of Law, University of Zagreb, Nazorova 51, 10000 Zagreb, Hrvatska / Croatia, marina.ajdukovic@pravo.hr
} 
manju snagu kao čimbenik zaštite nego kod majki obitelji s NRS-om. Nalaz da je 8,7\% majki iz obitelji u niskom riziku od siromaštva i 20,2\% majki u visokom riziku od siromaštva visoko rizično za zlostavljanje djece analizira se pod vidom većeg broja socioekonomskih prediktora i mogućnosti djelotvornog integriranog pristupa obiteljima s djecom u visokom riziku od siromaštva.

Ključne riječi: siromaštvo, kvaliteta obiteljskih odnosa, rizik za zlostavljanje djece.

\section{UVOD}

Tema siromaštva djece je u posljednjih pet godina privukla značajnu pozornost istraživača u Hrvatskoj. Ključne istraživačke projekte o ovoj temi su u navedenom razdoblju provodili različiti timovi znanstvenika Studijskog centra socijalnog rada Pravnog fakulteta u Zagrebu koji su, očekivano, imali i imaju vodeću ulogu u istraživanjima koja omogućavaju bolje razumijevanje obilježja, odrednica, posljedica i neposrednih i dugoročnih ishoda siromaštva djece u hrvatskom kontekstu. Prvo ciljano i opsežno istraživanje »Siromaštvo i dobrobit djece predškolske dobi u Republici Hrvatskoj « proveli su uz potporu UNICEF-a 2014. godine Šućur, Kletečki Radović, Družić Ljubotina i Babić (2015.). Ovom istraživanju prethodile su analize ključnih statističkih pokazatelja značajnih za razumijevanje opsega i pristupa siromaštvu djece (Babić, 2013.; Stubbs i Zrinščak, 2014.). U razdoblju od 2014. do 2016. godine provodio se, uz financijsku potporu Zaklade Adris, projekt »Indikatori dobrobiti i siromaštva djece u Hrvatskoj u doba krize: kako prekinuti začarani krug siromaštva djece?«. Radilo se o složenom kvalitativnom istraživanju koje je po prvi put omogućilo da se uz stručnjake i donositelje odluka čuje i glas djece koja odrastaju u siromaštvu (Ajduković i Rimac, 2017.). O učinku odrastanja u siromaštvu na kasniji životni put djece i mladih odraslih u siromaštvu iznimno je značajno i istraživanje »Obrazovni ishodi i radne karijere mladih odraslih u siromaštvu« koje su proveli Rimac i suradnici u razdoblju od 2015. do 2016. uz financijsku podršku Europskog socijalnog fonda (Vučković Juroš i Tokić Milaković, 2016.; Rimac, Ogresta i Ružojčić, 2017.). U tijeku je longitudinalno istraživanje »Ekonomske teškoće obitelji, psihosocijalni problemi i obrazovni ishodi adolescenata u vrijeme ekonomske krize« koje također provodi istraživački tim Studijskog centra socijalnog rada Pravnog fakulteta u Zagrebu uz potporu Hrvatske zaklade za znanost (od 2015. do 2019.). Prvi rezultati ovog projekta već su prikazani na različitim međunarodnim i nacionalnim konferencijama (npr. Ajduković, Rajter i Rezo, 2017.; Sušac, Skokandić, Rimac i Družić Ljubotina, 2017.). Uz navedene istraživačke projekte znanstvenika Studijskog centra socijalnog rada Pravnog fakulteta u Zagrebu koji su, očekivano, imali i imaju vodeću ulogu u istraživanjima koja omogućavaju bolje razumijevanje obilježja, odrednica, posljedica i neposrednih i dugoročnih ishoda siromaštva djece u hrvatskom kontekstu, nezaobilazan je i istraživački doprinos Hrvatskog katoličkog sveučilišta koje je financiralo 2016. godine znanstveni projekt »Rad roditelja, ekonomske teškoće obitelji i dobrobit roditelja i djece « (Anđelinović, Vrselja, Merkaš, Pandžić, 2016.; Anđelinović, Merkaš, Brdovčak i Matijaš, 2017.) te istraživanje Stubbsa, Ledića, Rubila i Zrinščaka (2017.) »Dječje siromaštvo i strategije nošenja sa siromaštvom kućanstava u Hrvatskoj « provedeno 2016. godine također uz financijsku podršku Zaklade ADRIS. 
Iako je istraživačka aktivnost o siromaštvu djece sve bogatija i jasno ukazuje na nužnost djelovanja kao i na različite moguće inovativne iskorake u smanjivanju i olakšavanju posljedica siromaštava djece (Stubbs i Zrinščak, 2014.; Ajduković, Dobrotić i Matančević, 2017.; Stubbs i sur., 2017.), analize postojećih politika usmjerenih na siromaštvo i socijalnu isključenost ukazuju na pasivnu strategiju države i neusklađenost kako s relevantnim europskim okvirima poput Strategije Europa 2020 i Europske platforme protiv siromaštva i socijalne isključenosti, tako i s aktualnim nacionalnim dokumentima kao što je npr. Nacionalna strategija za prava djece u Republici Hrvatskoj za razdoblje od 2014. do 2020. godine (za detaljniji pregled pogledati Ajduković, Dobrotić i Matančević, 2017.). Navedeni dokumenti stavljaju naglasak na nužnost kombiniranja modernog pristupa dugoročnog socijalnog ulaganja kroz rani odgoj, obrazovanje i stručno osposobljavanje, uz tradicionalni pristup socijalne zaštite i brige države kroz zdravstvenu zaštitu i dostupne materijalne naknade, ali i druge oblike psihosocijalne podrške (Ajduković, Dobrotić i Matančević, 2017.; Stubbs i sur., 2017.).

S obzirom na očekivanja od sustava socijalne skrbi da, osim kroz materijalna davanja, proširi svoju ulogu u olakšavanju specifičnih posljedica siromaštva po dobrobit djece, potrebna su ciljana istraživanja različitih psihosocijalnih aspekta obiteljskog života i roditeljstva u obiteljima koje se suočavaju sa siromaštvom i rizikom siromaštva. Polazeći od toga, u ovom radu usmjerit ćemo se na čimbenike rizika za nasilne odgojne postupke i kvalitetu obiteljskog funkcioniranja obitelji koje su u visokom riziku od siromaštva. U tekstu koji slijedi kratko ćemo se osvrnuti na dosadašnje spoznaje o ovom području te na operacionalizaciju visokog rizika od siromaštva.

\section{Učinak siromaštva i financijskih poteškoća na obiteljske odnose i roditeljstvo}

Empirijski utemeljenu poveznicu razumijevanja odnosa između siromaštva i financijskih poteškoća s funkcioniranjem obitelji i roditeljstvom nudi model (ekonomskog) obiteljskog stresa. Model polazi od toga da ekonomske teškoće dovode do ekonomskog pritiska te zbog toga dolazi do frustracije, ljutnje i emocionalnog stresa kod roditelja (Conger, Rueter i Conger, 2000.), što je povezano s narušavanjem mentalnog zdravlja roditelja, porastom konflikata u obitelji te češćim korištenjem nasilnih roditeljskih postupaka.

Različita istraživanja su dosljedno pokazala da je siromaštvo povezano s više aspekata obiteljskih odnosa i roditeljstva kao što je npr. zadovoljstvo brakom, količina partnerskih sukoba i nasilja u partnerskom odnosu, usklađenost majke i oca u roditeljstvu (npr. Raboteg-Šarić i Pećnik, 2006.; Donnellan, Conger, McAdams i Neppl, 2009.; Dew i Yorgason, 2010.). Istraživanja odnosa između opće kvalitete funkcioniranja obitelji i niskih prihoda je iznenađujuće malo, ali njihovi rezultati pokazuju da bolje poznavanje dinamike odnosa u ovim obiteljima može pridonijeti boljem djelovanju sustava socijalne skrbi. Pod tim vidom posebno je zanimljivo istraživanje Mansfield, Dealy i Keitner (2013.) provedeno u Sjedinjenim Američkim Državama. U istraživanju su sudjelovale dvije skupine obitelji: obitelji koje nemaju niski prihod (dohodak iznad $133 \%$ nacionalne granice siromaštva) i obitelji s niskim prihodima (dohodak ispod nacionalne granice siromaštva). Korišten je McMasterov upitnik funkcioniranja obitelji (FAD) koji ispunjavaju svi članovi obitelji koji žive zajedno i imaju 12 godina ili više. Sastoji se od sedam skala: 1 . skala rješavanja problema (sposobnost obitelji da riješi probleme), 2. komunikacija (verbalna razmjena informacija između članova obi- 
telji), 3. uloge (način na koji članovi obitelji ispunjavaju obiteljske funkcije i odgovornosti), 4. emocionalna osjetljivost (mogu li članovi obitelji u različitom situacijama reagirati punim rasponom emocija i jesu li doživljene emocije prikladne za kontekst u kojem se pojavljuje), 5. emocionalna uključenost (sposobnost članova obitelji da budu uključeni i međusobno povezani i kvaliteta te uključenosti), 6. kontrola ponašanja (kako obitelj određuje standarde ponašanja, kako reagira kad je neko ponašanje ugrožavajuće ili kako reagira na ponašanje kojima se izražavaju primarne potrebe kao što je npr. jedenje, spavanje ili agresivnost) i 7. opća skala funkcioniranja obitelji (koliko dobro obitelj funkcionira u cjelini). Pokazalo se da se obitelji s obzirom na razinu primanja razlikuju samo u dvije dimenzije obiteljskog funkcioniranja - uloge i emocionalna uključenost. Također se pokazalo da se obitelji s niskim primanjima teže nose s članovima koji imaju probleme mentalnog zdravlja i da je njihovo nezadovoljstvo obiteljskim funkcioniranjem veće kad imaju članove s takvim poteškoćama. Autori smatraju da kada su materijalni resursi ozbiljno ograničeni, teže je raspodijeliti uloge $\mathrm{i}$ odgovornosti te pronaći zadovoljavajuće načine kako će se članovi obitelji emocionalno angažirati u obitelji, pogotovo kad neki članovi trebaju dodatnu emocionalnu pažnju zbog problema s mentalnim zdravljem. Upućuju da je potrebno pružiti dodatnu i specifičnu podršku upravo tim obiteljima koje imaju niske prihode. Ovi nalazi upućuju na važnost pružanja obiteljskih intervencija obiteljima s niskim prihodima u kojima jedan ili više članova ima identificiran psihički poremećaj.

U području učinka siromaštva i financijskih poteškoća na roditeljstvo, Raboteg-Šarić i Pećnik (2006.) su u opsežnom anketnom istraživanju o jednoroditeljskim obiteljima u Hrvatskoj utvrdile da su financijske poteškoće glavni prediktor roditeljske depresivnosti, a depresiv- niji roditelji manje su uključeni u odgoj djece, imaju slabiji nadzor nad dječjim aktivnostima i pružaju djeci manje podrške.

Što se tiče nasilnih odgojnih postupaka i rizika za zlostavljanje djece, brojna empirijska istraživanja i suvremeni modeli objašnjavanja zlostavljanja djece dosljedno navode kao značajnu skupinu čimbenika rizika socijalno-situacijske stresore kao što su npr. nezaposlenost roditelja, siromaštvo i socijalna izolacija obitelji (za detaljan pregled pogledati Ajduković i Rajter, 2013.). To su potvrdila i nacionalna istraživanja. Tako su Kalebić Jakupčević i Ajduković (2011.) $\mathrm{u}$ istraživanju rizika za tjelesno zluuostavljanje djece roditelja koji imaju dijagnosticirane psihičke probleme (PTSP očeva i anksiozno-depresivni poremećaj majki i očeva) utvrdile da su uz probleme mentalnog zdravlja, slabiji ekonomski status, manja socijalna podrška te tjelesna i verbalna agresija u partnerskim sukobima, značajni prediktori rizika za zlostavljanje djece. Benić (2018.) je u istraživanju u kojem su sudjelovali očevi djece 6., 7. i 8. razreda osnovne škole utvrdila da najznačajniji doprinos riziku za zlostavljanje djece imaju niski mjesečni prihodi, veća izloženost psihičkoj agresiji u partnerskom odnosu kao i starija dob, dok očevo bolje nošenje sa stresom smanjuje rizik za zlostavljanje djece.

Kao što je već navedeno, u ovom radu smo usmjereni na obitelji koje žive u visokom riziku od siromaštva. Razlog za to je što su novija međunarodna istraživanja pokazala da je nepovoljan odnos između prihoda i dobrobiti obitelji i djece najizraženiji upravo kod onih obitelji koje žive s vrlo niskim i niskim prohodima. Tako je npr. studija National Institute of Child Health and Human Development (NICHD) pokazala da je kod obitelji čiji prihod ne prelazi nacionalnu granicu siromaštva prisutna manja osjetljivost majke na potrebe djece i veća neučinkovitost njezinih odgojnih postupaka i kontrole u odnosu na majke u obiteljima 
iznad razine siromaštva (Mistry, Biesanz, Taylor, Burchinal i Cox, 2004.; Mistry, Lowe, Benner i Chien, 2008.).

Značajne spoznaje koje ukazuju na visoki razvojni rizik upravo kod djece iz najsiromašnijih obitelji dolaze $\mathrm{i}$ iz područja neuroznanosti. Tako su u složenom i metodološki izvrsno provedenom istraživanju Noble i sur. (2015.) potvrdili da su socioekonomske nejednakosti povezane s razlikama u kognitivnom razvoju djece, neovisno o genetskom podrijetlu. Konkretno, u istraživanju u kojem je sudjelovalo 1099 tipično razvijene djece i mladih između 3 i 20 godina, pokazalo se da je prihod logaritamski povezan $s$ površinom prefrontalnog korteksa te da su kod djece iz obitelji s nižim dohotkom male razlike u dohotku povezane s relativno velikim razlikama u strukturi prefrontalnog korteksa ${ }^{1}$. Ti su odnosi bili najistaknutiji u područjima koja podržavaju govor, čitanje, izvršne funkcije i prostorne sposobnosti. Ovi podaci upućuju na to da je veza prihoda i strukture mozga najvidljivija kod djece u najnepovoljnijim ekonomskim situacijama.

Istodobno, u nas su dosadašnje spoznaje o učincima materijalne deprivacije na odnose u obitelji i roditeljstvo bile ishod usputnih nalaza istraživanja koja su imala u fokusu neke druge fenomene $\mathrm{i} / \mathrm{ili}$ bila provedena na uzorcima opće populacije (npr. Kalebić Jakupčević i Ajduković, 2011.; Benić, 2018.).

Polazeći od navedenog, u ovom radu smo se usmjerili na ciljanu skupinu roditelja koji žive u siromaštvu i visokom riziku od siromaštva, te njihovu usporedbu s roditeljima koji su u niskom riziku od siromaštva. Kao relativno objektivnu razdjelnicu između ove dvije skupine koristili smo pokaza- telje obiteljskih prihoda koji su kriterij za ostvarivanje prava na dječji doplatak.

Uz zajamčenu minimalnu naknadu, dječji doplatak je jedan od glavnih državnih programa za djecu u Hrvatskoj (Stubbs i Zrinščak, 2014.). Svrha doplatka za djecu je »potpora uzdržavanju i odgoju djece« (Zakon o doplatku za djecu, NN, 58/2018., članak 1.) Za dječji doplatak i druga novčana davanja izdvajaju se oko dvije trećine javnih ulaganja, dok se na programe usluga skrbi i predškolskog odgoja i obrazovanja izdvaja tek jedna trećina (Babić, 2013.). Izmjenama i dopunama Zakona o dječjem doplatku (NN, 58/2018.) ova izdvajanja će biti još veća. Na važnost državnih davanja i ulaganja za smanjenje rizika od siromaštva ukazuju i podaci Državnog zavoda za statistiku (2016.) koji govore o značajnoj ovisnosti stope rizika od siromaštva o socijalnim transferima. Stopa rizika od siromaštva prije socijalnih transfera (a bez uključenih mirovina) za djecu mlađu od 18 godina iznosi $39,7 \%$, dok stopa rizika od siromaštva nakon socijalnih transfera iznosi 20,9\%. S druge strane, novčana davanja od države nisu usklađena s promjenama u troškovima života, nego su izmjenama Zakona o socijalnoj skrbi iz 2013. bila dodatno i smanjena, posebice na štetu obitelji s više djece (Ajduković, Dobrotić i Matančević, 2017.). Upozoravajuće podatke daju i nalazi istraživanja prema kojem dječji doplatak predstavlja nužni izvor prihoda cjelokupnog kućanstva u radno neaktivnim kućanstvima s većim brojem djece (Bagić, Dobrotić, Lažnjak, Rodik i Vučković Juroš, 2017.) što nije primarna svrha dječjeg doplatka. Podsjetimo se, svrha dječjeg

\footnotetext{
${ }^{1}$ Prefrontalni korteks sudjeluje u obradi informacija vezanih uz više kognitivne i polisenzoričke funkcije. Upravlja voljnim i drugim prilagođenim ponašanjem te se može smatrati u funkcionalnoj hijerarhiji najvišim područjem moždane kore. uVažan je za procesiranje informacija, socijalno prosuđivanje, planiranje aktivnosti, ali služi i kao »kočnica« nekontroliranim emocionalnim reakcijama. Prefrontalni korteks mozga je područje u kojem se najviše promjena odvija u adolescenciji. Razvoj prefrontalnog korteksa djece vrlo je osjetljiv na faktore okoline, kao što je stres, nedostatak kognitivne stimulacije, loša prehrana i razlike u dostupnosti i kvaliteti zdravstvene skrbi (Center for Neuroscience \& Society, University of Pennsylvania; https://neuroethics.upenn.edu/).
} 
doplatka je potpora uzdržavanju i odgoju djece, a ne uzdržavanju cijelog kućanstva. Prema trenutnim odredbama, korištenje dječjeg doplatka uvjetovano je primanjima manjim od 50 posto proračunske osnovice (1 663 kune), pri čemu obitelji koje po članu ostvaruju prihod do 543,14 kuna imaju pravo na 299,34 kune dječjeg doplatka po djetetu, zatim obitelji koje po članu ostvaruju prihod od 543,14 do 1 119,53 kune, imaju pravo na 249,45 kuna te naposljetku obitelji s prihodom od 1119,53 do 1663 kune ostvaruju pravo na 199,56 kuna po djetetu. Izmjenama i dopunama Zakona o doplatku (NN, 58/2018.) proširuje se broj obitelji koje od 1. srpnja imaju pravo na dječji doplatak na kućanstva koja imaju primanja manja od 70 posto proračunske osnovice (2 328 kuna). Tako će biti obuhvaćen veći broj obitelji koje žive u ekonomskim teškoćama, no visina dječjeg doplatka neće se mijenjati, te se neće povećati njegova visina za najugroženije skupine što bi, polazeći od suvremenih neuroznanstvenih istraživanja, bilo nužno (Noble i sur., 2015.). U ovom istraživanju bit ćemo usmjereni na roditeljstvo i obiteljske odnose roditelja koji žive u visokom riziku od siromaštva i nakon socijalnih transfera.

\section{CILJ ISTRAŽIVANJA}

Cilj istraživanja je istražiti doprinos objektivnih i subjektivnih pokazatelja socioekonomskog statusa, izloženosti stresnim događajima i dostupnosti socijalne podrške kvaliteti obiteljskih odnosa i riziku za zlostavljanje djece kod majki adolescenata u obiteljima izloženim visokom i niskom riziku od siromaštva. mi su:

Polazeći od toga, istraživački proble-

1. Usporediti kvalitetu obiteljskog funkcioniranja i rizičnost za zlostavljanje djece u obiteljima izloženim visokom i niskom riziku od siromaštva.

2. Ispitati doprinos objektivnih i subjektivnih pokazatelja socioekonomskog statusa kvaliteti obiteljskog funkcioniranja i rizika za zlostavljanje adolescenata u obiteljima izloženim visokom i niskom riziku od siromaštva.

3. Ispitati ulogu socijalne podrške kao zaštitnog čimbenika u objašnjenju kvalitete obiteljskog funkcioniranja i rizičnosti za zlostavljanje adolescenata u obiteljima izloženim visokom i niskom riziku od siromaštva.

Za operacionalizaciju visokog odnosno niskog rizika od siromaštva korišten je podatak o prosječnom prihodu obitelji po članu domaćinstva. Kriterij za klasifikaciju obitelji u one s visokim i niskim rizikom siromaštva usklađen je s cenzusom za primanja većeg doplatka za djecu (I. i II. skupina primatelja dječjeg doplatka - visoka razina rizika od siromaštva) u odnosu na one koji nemaju pravo na dječji doplatak temeljem izmjena i dopuna Zakona o dječjem doplatku (NN, 58/2018.) (niska razina rizika od siromaštva).

\section{METODA}

\section{Sudionici}

Podaci prikazani u ovom radu prikupljeni su u sklopu većeg istraživačkog projekta »Ekonomske teškoće obitelji, psihosocijalni problemi i obrazovni ishodi adolescenata $\mathrm{u}$ vrijeme ekonomske krize«, financiranog od Hrvatske zaklade za znanost. Istraživanje je provedeno u 6 županija središnje Hrvatske: Karlovačka županija, Međimurska županija, Sisačko-moslavačka županija, Varaždinska županija, Grad Zagreb i Zagrebačka županija. Uzorak istraživanja je dvoetapni neproporcionalno stratificirani klaster uzorak pri čemu su u prvoj etapi odabrane srednje škole (trogodišnje strukovne škole, četverogodišnje strukovne škole te gimnazije), a u drugoj razredna odjeljenja koja predstavljaju klastere koji se u cijelosti uključuju u uzorak. U glavnom istraživanju sudjelovali su učenici prvih razreda srednjih škola oda- 
branih razrednih odjeljenja $(\mathrm{Mdob}=15,13$; SDdob $=0,448 ; 52,2 \%$ djevojke) i njihove majke, dok su u ovom radu, u skladu s ciljem i istraživačkim problemima prikazani samo rezultati koji se odnose na majke.

Majkama svih učenika koji su sudjelovali $\mathrm{u}$ istraživanju ( $\mathrm{N}=1169)$ poslani su odgovarajući upitnici. Ukupno 843 (72,11\%) majki vratile su ispunjene upitnike, no njih $96(11,3 \%)$ nisu odgovorile na sva pitanja korištena u upitnicima. Konačni uzorak od 747 majke (Mdob = 42,89; SDdob = 5,343) je inicijalni uzorak za sva specifična istraživačka pitanja i analize. Kako niti u jednoj korištenoj varijabli nije bilo više od $5 \%$ nedostajućih vrijednosti, korištena je listwise metoda za isključivanje podataka koji nedostaju.

Karakteristike uzorka u mnogome odgovaraju demografskim podacima obitelji s djecom u Hrvatskoj (Državni zavod za statistiku, 2016.). Većinu uzorka čine sudionice sa završenom srednjom školom $(25,4 \%$ trogodišnja strukovna škola, 39,2\% četverogodišnja škola; ukupno 64,6\%), zatim sudionice s visokoškolskim obrazovanjem (ukupno 19,9\%), majke s osnovnoškolskim obrazovanjem $(13,3 \%)$ te $2,1 \%$ majki s nedovršenom osnovnom školom. Većina majki je u braku $(84,6 \%)$ te ima jedno $(41,4 \%)$ ili dvoje djece $(40,1 \%)$. Gotovo polovica obitelji $(42,4 \%)$ prima dječji doplatak, državnu mjeru usmjerenu na smanjivanje rizika od siromaštva djece, te se mogu smatrati kao obitelji koje se suočavaju s ekonomskim teškoćama i rizikom od siromaštva. Dodatnih $5,1 \%$ obitelji primaju državnu zajamčenu novčanu pomoć te se mogu smatrati obiteljima koje žive u siromaštvu.
Polazeći od ciljeva ovog rada, za analize su korišteni podaci tzv. ekstremnih skupina s obzirom na financijsku situaciju obitelji obitelji koje žive u visokom riziku od siromaštva i obitelji koje žive u niskom riziku od siromaštva. Uzorak koji je korišten za ovo istraživanje odnosi se na ukupno 392 majke. Tako su u skupinu obitelji koje žive u visokom riziku od siromaštva ušle 163 majke $(22,5 \%)$ koje žive u obiteljima u kojima je prosječni dohodak ${ }^{2}$ po članu obitelji manji od 1225 kuna. To po aktualnim propisima odgovara obiteljima koje zbog slabog imovinskog statusa ostvaruju pravo na višu razinu dječjeg doplatka. Potrebno je napomenuti da navedeni iznosi predstavljaju primanja nakon socijalnih transfera, odnosno uključuju i dječji doplatak te su ih iskazale majke. U skupinu koja predstavlja obitelji koje žive u niskom riziku od siromaštva ušlo je 229 majki $(31,7 \%)$ koje žive u obiteljima čiji je prosječni dohodak po članu obitelji veći od 2400 kuna, što ih po sadašnjim propisima ne kvalificira za primanje dječjeg doplatka.

Na opravdanost ove kategorizacije obitelji ukazuju i sljedeći podaci. U ovom uzorku prosječni prihod po članu u obiteljima koje su u visokom riziku od siromaštva iznosi 719,14 kuna (SD = 308,86), a u obiteljima koje su svrstane u skupinu niskog rizika od siromaštva, prosječni prihod po članu iznosi 3 357,53 kuna $(\mathrm{SD}=838,14)$. U skladu s tim su i podaci o udjelu primatelja dječjeg doplatka u ove dvije skupine. Tako su u skupini visokog rizika od siromaštva njih 85,6\% korisnici dječjeg doplatka, a u skupini niskog rizika od siromaštava njih $10,4 \%$. Polazeći od velikog standardnog

\footnotetext{
${ }^{2}$ Naglašavamo da se ovdje radi o prosječnom dohotku obitelji koji je izračunat temeljem iskaza majki o ukupnom prihodu obitelji koji je naknadno podijeljen s brojem članova obitelji. Za razliku od toga, ekvivalentni raspoloživi dohodak računa se tako da se ukupan raspoloživi dohodak kućanstva podijeli s ekvivalentnom veličinom kućanstva izračunatom prema modificiranoj OECD-ovoj ljestvici, prema kojoj se nositelju kućanstva dodjeljuje koeficijent 1, svakoj drugoj odrasloj osobi u kućanstvu od 14 godina i starijoj osobi koeficijent 0,5 , a djeci mlađoj od 14 godina koeficijent 0,3 . Postupak se primjenjuje zbog određivanja ravnomjernijeg udjela svakog člana kućanstva u stjecanju zajedničkog prihoda.
} 
raspršenja prihoda po članu obitelji u ovoj skupini, po svemu sudeći, radi se o obiteljima koje pravo na dječji doplatak u najmanjem iznosu (199,56 kuna po djetetu) ostvaruju temeljem prihoda od 1 119,53 do 1663 kune po članu obitelji. Upravo zbog opisanog načina definiranja uzorka u ovom istraživanju, korištena je sintagma »rizik od siromaštva«. Naime, u našem istraživanju u tzv. ekstremnoj skupini majki koje su u visokom riziku od siromaštva nalaze se i majke koje su korisnice minimalne novčane naknade kao i majke iz obitelji koje zbog slabog imovinskog statusa ostvaruju pravo na višu razinu dječjeg doplatka.

\section{Instrumenti}

Upitnik sociodemografskih podataka obuhvaća podatke o obrazovnom i radnom statusu roditelja i prosječnom dohotku po članu obitelji koji zajednički predstavljaju objektivne mjere socioekonomskog statusa. Obrazovni status mjeren je kao stupanj završenog obrazovanja majki i operacionaliziran je kroz devet odgovora: 1. Nije išla/ išao u školu; 2. Nedovršena osnovna škola; 3. Završena osnovna škola; 4. Srednja strukovna škola u trajanju od 3 godine; 5 . Četverogodišnja strukovna srednja škola; 6 . Gimnazija; 7. Stručni studij, viša ili visoka; 8. Fakultet - diplomski sveučilišni studij; 9. Poslijediplomski studij, a sudionice su odgovarale posebno za vlastiti obrazovni status, posebno za očev obrazovni status. $\mathrm{U}$ istraživanju se koristila samo varijabla majčinog obrazovnog statusa iz dva razloga. Prvi je što se u istraživanju stavlja fokus na varijable koje se vežu uz majku, kao što je npr. majčin rizik na zlostavljanje djece. Drugi razlog je osiguravanje parsimoničnosti istraživanog modela, posebice uzevši u obzir da je korelacija majčinog i očevog obrazovnog statusa visoka $(\mathrm{r}=0,644)$. Radni status roditelja mjeren je binarno - radi ili ne radi, odvojeno za majku i oca, a zatim je kreirana jedna varijabla $» Z$ Zaposlenost rodi- telja« koja govori o ukupnom broju zaposlenih roditelja u obitelji na tri stupnja $(0$ - niti jedan roditelj nije zaposlen, 1 - jedan roditelj zaposlen, 2 - oba zaposlena roditelja). Prosječni dohodak po članu obitelji također je naknadno kreiran tako da se ukupan dohodak kućanstva podijelio s veličinom kućanstva, odnosno brojem članova kućanstva koje su sudionice naznačile.

Uz objektivne mjere socioekonomskog statusa, korištene su i subjektivne mjere ekonomskog pritiska s dva instrumenta: Upitnik materijalne deprivacije (Ajduković, Družić Ljubotina i Kletečki Radović, 2016.) i Upitnik učinka financijskih poteškoća na odnose u obitelji (Rajhvajn Bulat, Ajduković i Sušac, 2016.).

Upitnik materijalne deprivacije (Ajduković, Družić Ljubotina i Kletečki Radović, 2016.) adaptiran je za potrebe istraživanja na temelju pitanja o materijalnom statusu obitelji koja se koriste u svrhu kreiranja Statističkog ljetopisa Državnog zavoda za statistiku. Sastoji se od četiri čestice na koje su sudionice odgovarale na skali od tri stupnja (1 - nikad, 2 -ponekad i 3 - često ili uvijek): »Kasnimo s plaćanjem najamnine, računa za režije, stambenoga kredita ili potrošačkoga kredita jer nemamo dovoljno novca.«; »Možemo priuštiti svim članovima obitelji tjedan dana godišnjeg odmora izvan kuće.«; »Možemo si priuštiti obrok koji sadrži meso, piletinu, ribu ili vegetarijanski nadomjestak najmanje svaki drugi dan.«; »U mogućnosti smo podmiriti neki neočekivani financijski trošak (npr. kvar nekog kućanskog aparata).«Ukupni rezultat predstavlja suma odgovora, a niži rezultat upućuje na veću materijalnu deprivaciju. Unutarnja pouzdanost skale u ovom istraživanju iznosi $\alpha=0,75$.

Upitnik učinka financijskih poteškoća na odnose u obitelji (Rajhvajn Bulat, Ajduković i Sušac, 2016.) sastavljen je za potrebe istraživanja na temelju provedenog pilot istraživanja. Sastoji se od četiri čestice koje 
su sudionice procjenjivale na skali od 1 nikad do 5 - uvijek: »Zabrinuta sam zbog financijske situacije svoje obitelji.«; »Novac je izvor sukoba u mojoj obitelji.«, »Članovi moje obitelji razgovaraju o financijskim problemima naše obitelji.«; »Odnosi u mojoj obitelji su narušeni zbog problema $s$ novcem.«Ukupni rezultat dobiva se kao prosjek svih odgovora sudionica, pri čemu viši rezultat upućuje na višu razinu utjecaja financijskih teškoća na obiteljske odnose. Unutarnja pouzdanost skale u ovom istraŽivanju iznosi $\alpha=0,85$.

Nakon objektivnih i subjektivnih mjera ekonomskog pritiska, korištene su mjere stresa kod majki: Upitnik suočavanja s ekonomskim teškoćama obitelji (Ajduković, Družić Ljubotina i Kletečki Radović, 2016.) i Upitnik svakodnevnog stresa i doživljenih stresora (Ajduković, Rajter i Sušac, 2011.).

Upitnik suočavanja s ekonomskim teškoćama obitelji (Ajduković, Družić Ljubotina i Kletečki Radović, 2016.) kreiran je za potrebe ovog istraživanja na temelju provedenog pilot istraživanja. Korištena je jedna subskala pod nazivom »Posramljenost zbog financijske situacije«. Sudionice su procjenjivale tri čestice na skali od 1 - nikad do 3 - često: »U posljednjih 12 mjeseci ste izbjegavali prijatelje ili članove šire obitelji zbog nedostatka novaca?«, »U posljednjih 12 mjeseci ste imali osjećaj da Vas izbjegavaju prijatelji ili članovi šire obitelji zbog Vaših problema s novcem?«, »U posljednjih 12 mjeseci ste imali osjećaj posramljenosti pred djecom jer niste imali novca za nešto što im je bilo potrebno?«). Viši rezultat označava veći osjećaj posramljenosti zbog financijske situacije. Unutarnja pouzdanost skale u ovom istraživanju iznosi $\alpha=0,77$.

Upitnik svakodnevnog stresa i doživljenih stresora (Ajduković, Rajter i Sušac, 2011.) prilagođen je za ovo istraživanje. Sastoji se od 18 tvrdnji koje opisuju stresne događaje (npr. »Preseljenje«; »Problemi u partnerskom odnosu«; »Vlastita tjelesna bolest ili ozlje- da«; »Psihički problem(i) člana uže obitelj«), a sudionice odgovaraju s »da ili »ne« na pitanje jesu li doživjele takav događaj u zadnje tri godine. Ukupni rezultat formiran je kao zbroj potvrdnih odgovora na pojedine tvrdnje te viši rezultat upućuje na veću izloženost stresnim događajima majki.

Višedimenzionalna skala percipirane socijalne podrške (MSPSS; Zimet i sur., 1988.) korištena je kao mjera percipirane socijalne podrške obitelji, prijatelja i partnera. Sastoji se od 12 čestica na koje su sudionice odgovarale na skali o d 1 - uopće se ne slažem do 7 - u potpunosti se slažem. Ukupni rezultat dobiva se kao prosjek svih odgovora sudionica, a viši rezultat ukazuje na doživljaj veće socijalne podrške. Unutarnja pouzdanost skale dobivena u ovom istraživanju iznosi $\alpha=0,94$, što je u skladu $\mathrm{s}$ pouzdanosti dobivenom u istraživanju autora skale ( $\alpha=0,88$; Zimet i sur., 1988.).

Skala obiteljskog funkcioniranja (ICPS; Noller, 1988.) instrument je za mjerenje bliskosti u obitelji, obiteljskih konflikata i roditeljskog stila na tri istoimene subskale. U ovom istraživanju korištene su dvije subskale - subskala bliskosti u obitelji koja mjeri količinu osjećaja bliskosti, dijeljenja osobnih doživljaja te otvorenosti u komunikaciji unutar obitelji te subskala konflikta koja mjeri razinu nerazumijevanja i teškoća u rješavanju problema unutar obitelji. Sudionice su procjenjivale 22 čestice na skali od 1 - uopće se ne slažem do 6 - u potpunosti se slažem, a ukupni rezultat po subskalama definiran je kao suma tvrdnji na pojedinoj subskali. Subskala bliskosti u ovom istraživanju pokazuje visoku pouzdanost od $\alpha=$ 0,92 , a subskala konflikata zadovoljavajuću pouzdanost od $\alpha=0,77$, što je u skladu s pouzdanostima dobivenim u autorovom istraživanju gdje je subskala bliskosti imala pouzdanost također $\alpha=0,92$, a subskala konflikata $\alpha=0,82$ (Noller, 1992.).

Na kraju, korišten je Inventar rizičnosti za zlostavljanje (Child Abuse Potential In- 
ventory - CAPI; Milner, 1986.) koji mjeri rizičnost za zlostavljanje djeteta kroz različite aspekte roditeljske psihološke prilagodbe i odnosa s drugima. Sastoji se od 77 čestica koje sudionice procjenjuju s odgovorima »Slažem se « ili »Ne slažem se «. Rezultat predstavlja utežanu linearnu kombinaciju, a teoretski rezultat može varirati od 0 do 486, pri čemu viši rezultat ukazuje na veću rizičnost za zlostavljanje djece. Unutarnja pouzdanost skale u ovom istraživanju iznosi $\alpha=0,91$, slično kao u međunarodnim istraživanjima gdje je Cronbach alfa iznosio od 0,89 do 0,94 (Milner i Crouch, 2012.), a $\mathrm{u}$ prethodnim nacionalnim istraživanjima iznosio je od 0,91 do 0,97 (Pećnik, 2003.; Kalebić Jakupčević i Ajduković, 2011.; Benić,u 2018.).

\section{Postupak}

Istraživanje je provedeno od veljače do svibnja 2016. godine. Prethodno su članovi istraživačkog tima proveli roditeljske sastanke u odabranim školama gdje su informirali roditelje o svrsi istraživanju i pozvali majke na sudjelovanje u istraživanju. Majke koje nisu prisustvovale roditeljskom sastanku dobile su pisane informacije i poziv na sudjelovanje u istraživanju. Zajamčena im je anonimnost i povjerljivost podataka prikupljenih istraživanjem. Majke koje su pristale na istraživanje ispunile su upitnike kod kuće te ih poslale u školu.

Majke su isključive sudionice istraživanja zbog prethodnog istraživačkog iskustva koje pokazuje da prilikom pozivanja bilo kojeg od roditelja na sudjelovanje u istraži- vanju, uglavnom majke ispune upitnik, što se pokazuje i u stranim istraživanjima (npr. McConnell, Breitkreuz i Savage, 2010.). Primjerice, u epidemiološkoj studiji nasilja nad djecom u Hrvatskoj BECAN koje je obuhvatilo 2831 roditelja samo 12,9\% sudionika činili su očevi (Rajter, 2013.). Osim toga, u istraživanjima se pokazuje i da su majke češće odgovornije za upravljanje obiteljskim budžetom te osjetljivije na financijske poteškoće obitelji (Mistry i sur., 2008.).

Prije provedbe istraživanja dobiveno je odobrenje Ministarstva znanosti, obrazovanja i sporta Republike Hrvatske te Etičkog odbora Pravnog fakulteta Sveučilišta u Zagrebu.

Podaci su analizirani u okviru SPSS programskog paketa. Za odgovaranje na istraživačke probleme, korištene su složena analiza varijance i hijerarhijska regresijska analiza.

\section{REZULTATI}

Prije prikaza rezultata pod vidom istraživačkih pitanja, prikazat ćemo osnovne statističke parametre za sve varijable koje smo koristili u daljnjim analizama. Složenom analizom varijance ispitane su razlike s obzirom na prosječni prihod obitelji po članu kućanstva, kao nezavisne varijable, sa svim ostalim varijablama kao zavisnim varijablama. Rezultati analize pokazali su statistički značajni multivarijatni efekt (Wilk's $\lambda=0,397 ; \mathrm{F}=57,945 ; \mathrm{df}=10,381$; $\left.\mathrm{p}<0,001 ; \eta_{\mathrm{p}}{ }^{2}=0,603\right)$. U tablici 1. nalaze se rezultati univarijatnih testova. 
Tablica 1.

Složena analiza varijance s prosječnim prihodom kućanstva kao pokazateljem visokog i niskog rizik od siromaštva kao nezavisne varijable i svih ostalih varijabli kao zavisnim varijablama

\begin{tabular}{|c|c|c|c|c|c|c|c|}
\hline Varijabla & $\begin{array}{c}\text { Rizik od } \\
\text { siromaštva }\end{array}$ & $\mathrm{N}$ & M & SD & $\mathrm{F}$ & $\mathrm{p}$ & $\eta_{p}^{2}$ \\
\hline \multirow{2}{*}{$\begin{array}{l}\text { Rizičnost za zlostavljanje } \\
\text { djece }\end{array}$} & Visoki & 163 & 141,33 & 92,75 & \multirow{2}{*}{36,58} & \multirow{2}{*}{0,000} & \multirow{2}{*}{0,086} \\
\hline & Niski & 229 & 89,72 & 75,82 & & & \\
\hline \multirow{2}{*}{$\begin{array}{l}\text { Obiteljsko funkcioniranje: } \\
\text { bliskost }\end{array}$} & Visoki & 163 & 58,80 & 10,45 & \multirow{2}{*}{2,64} & \multirow{2}{*}{0,105} & \multirow{2}{*}{0,007} \\
\hline & Niski & 229 & 60,34 & 8,24 & & & \\
\hline \multirow{2}{*}{$\begin{array}{l}\text { Obiteljsko funkcioniranje: } \\
\text { konflikt }\end{array}$} & Visoki & 163 & 29,74 & 8,67 & \multirow{2}{*}{13,48} & \multirow{2}{*}{0,000} & \multirow{2}{*}{0,033} \\
\hline & Niski & 229 & 26,67 & 7,77 & & & \\
\hline \multirow{2}{*}{ Obrazovni status majke } & Visoki & 163 & 3,82 & 1,21 & \multirow{2}{*}{229,23} & \multirow{2}{*}{0,000} & \multirow{2}{*}{0,370} \\
\hline & Niski & 229 & 6,10 & 1,62 & & & \\
\hline \multirow{2}{*}{ Zaposlenost roditelja } & Visoki & 163 & 0,87 & 0,72 & \multirow{2}{*}{200,44} & \multirow{2}{*}{0,000} & \multirow{2}{*}{0,339} \\
\hline & Niski & 229 & 1,73 & 0,49 & & & \\
\hline \multirow{2}{*}{$\begin{array}{l}\text { Materijalna deprivacija } \\
\text { obitelji }\end{array}$} & Visoki & 163 & 8,03 & 1,79 & \multirow{2}{*}{318,45} & \multirow{2}{*}{0,000} & \multirow{2}{*}{0,450} \\
\hline & Niski & 229 & 10,90 & 1,40 & & & \\
\hline \multirow{2}{*}{$\begin{array}{l}\text { Učinak financijskih teškoća } \\
\text { na odnose u obitelji }\end{array}$} & Visoki & 163 & 17,39 & 4,61 & \multirow{2}{*}{108,53} & \multirow{2}{*}{0,000} & \multirow{2}{*}{0,218} \\
\hline & Niski & 229 & 12,48 & 4,58 & & & \\
\hline \multirow{2}{*}{ Broj stresnih događaja } & Visoki & 163 & 3,90 & 2,64 & \multirow{2}{*}{16,01} & \multirow{2}{*}{0,000} & \multirow{2}{*}{0,039} \\
\hline & Niski & 229 & 2,93 & 2,11 & & & \\
\hline \multirow{2}{*}{$\begin{array}{l}\text { Posramljenost zbog } \\
\text { financijske situacije }\end{array}$} & Visoki & 163 & 4,66 & 1,67 & \multirow{2}{*}{96,69} & \multirow{2}{*}{0,000} & 0 \\
\hline & Niski & 229 & 3,39 & 0,85 & & & 0,199 \\
\hline & Visoki & 163 & 70,15 & 11,67 & & & \\
\hline socijaina poarska & Niski & 229 & 73,24 & 11,60 & 0,12 & 0,010 & 0,016 \\
\hline
\end{tabular}

Univarijatne analize pokazale su da samo kod komponente obiteljskog funkcioniranja koja se odnosi na bliskost članova obitelji nije dobivena statistički značajna razlika prema prosječnom prihodu obitelji. Očekivano, s obzirom na kriterij podjele u ove dvije grupe, od preostalih varijabli najveće razlike su kod materijalne depri- vacije i zaposlenosti roditelja. Zanimljivo je uočiti kako razlika prema obrazovnom statusu majke ima viši efekt nego razlika prema zaposlenosti roditelja. Posebno ćemo se osvrnuti na materijalnu deprivaciju kako bismo bolje opisali svakodnevicu ove dvije skupine obitelji. 
Tablica 2.

Pokazatelji materijalna deprivacije u obiteljima visokog $(N=163)$ i niskog $(N=229)$ rizika od siromaštva

\begin{tabular}{|c|c|c|c|c|c|c|c|c|}
\hline \multirow[t]{2}{*}{ Varijabla } & \multirow[t]{2}{*}{$\begin{array}{l}\text { Rizik od } \\
\text { siromaštva }\end{array}$} & \multirow[t]{2}{*}{$\mathrm{N}$} & Nikad & Ponekad & $\begin{array}{l}\text { Često } \\
\text { ili } \\
\text { uvijek }\end{array}$ & \multirow[t]{2}{*}{$\chi^{2}$} & \multirow[t]{2}{*}{$p$} & \multirow[t]{2}{*}{ V } \\
\hline & & & $\%$ & $\%$ & $\%$ & & & \\
\hline \multirow{2}{*}{$\begin{array}{l}\text { Kasnimo s plaćanjem } \\
\text { najamnine, računa za } \\
\text { režije, stambenoga } \\
\text { kredita }\end{array}$} & Visoki & 163 & 31,9 & 49,7 & 18,4 & \multirow[b]{2}{*}{87,94} & \multirow[b]{2}{*}{0,000} & \multirow[b]{2}{*}{0,474} \\
\hline & Niski & 229 & 77,3 & 21,0 & 1,7 & & & \\
\hline \multirow{2}{*}{$\begin{array}{l}\text { Možemo priuštiti svim } \\
\text { članovima obitelji tjedan } \\
\text { dana godišnjeg odmora }\end{array}$} & Visoki & 163 & 62,6 & 33,1 & 4,3 & \multirow{2}{*}{168,02} & \multirow{2}{*}{0,000} & \multirow{2}{*}{0,655} \\
\hline & Niski & 229 & 8,3 & 33,6 & 58,1 & & & \\
\hline \multirow{2}{*}{$\begin{array}{l}\text { Možemo si priuštiti obrok } \\
\text { koji sadrži meso, piletinu, } \\
\text { ribu ili ekvivalent svaki } \\
\text { drugi dan }\end{array}$} & Visoki & 163 & 4,3 & 39,9 & 55,8 & \multirow[b]{2}{*}{73,82} & \multirow[b]{2}{*}{0,000} & \multirow[b]{2}{*}{0,434} \\
\hline & Niski & 229 & 1,3 & 6,1 & 92,6 & & & \\
\hline \multirow{2}{*}{$\begin{array}{l}\text { U mogućnosti smo } \\
\text { podmiriti neki neočekivani } \\
\text { financijski trošak }\end{array}$} & Visoki & 163 & 22,1 & 59,5 & 18,4 & \multirow{2}{*}{133,21} & \multirow{2}{*}{0,000} & \multirow{2}{*}{0,583} \\
\hline & Niski & 229 & 2,6 & 21,0 & 76,4 & & & \\
\hline
\end{tabular}

Očekivano, kod sva četiri pokazatelja materijalne deprivacije obitelji koje smo po prethodno opisanom kriteriji kategorizirali u skupinu visokog rizika za siromaštvo su u nepovoljnijem položaju. Sve razlike su statistički značajne uz rizik manji od $1 \%$. $^{3}$

\section{Kvaliteta obiteljskog funkcioniranja i rizik za zlostavljanje djece $u$ obiteljima izloženim visokom i niskom riziku od siromaštva}

U skladu s Congerovim modelom obiteljskog stresa, u obiteljima koje su u visokom riziku od siromaštva konflikti u obitelji su statistički značajno češći u odnosu na obitelji koje su u niskom riziku (tablica
1.). Analiza odgovora na pojedine čestice Skale obiteljskog funkcioniranja (subskala konflikti) pokazala je da su u obiteljima koje su u visokom riziku od siromaštva značajno češći ljutnja i nerazumijevanje među članovima obitelji te napetost među roditeljima u vezi odgoja djece (razlike na razini $\mathrm{p}<0,01$ prisutne $\mathrm{u} 7$ od 10 tvrdnji). Uz to, u tim obiteljima teže se donose odluke i teže se uvode promjene, a o problemima se lakše razgovara s ljudima izvan kruga obitelji. No, ono što je dobar pokazatelj je da se ove dvije skupine obitelji ne razlikuju značajno s obzirom na stupanj bliskosti među članovima. Analiza odgovora na pojedine čestice subskale bliskosti ipak je pokazala značajne razlike između ove dvije skupine

\footnotetext{
${ }^{3}$ Ovi podaci se tek okvirno uvjetno mogu usporediti s podacima Ankete o dohotku stanovništva za 2016. (te godine provedeno je ovo istraživanje) (DZS, 2017.). Naime, u našem istraživanju koristili smo trihotomiziranu mogućnost odgovora (nikad, ponekad, često ili uvijek), dok su podaci DSZ-a dihotomizirani (da - ne odgovori). Podaci DZS-a (2017.) pokazuju da u Hrvatskoj 25,7\% osoba živi u kućanstvima koja su u posljednjih 12 mjeseci zbog financijskih poteškoća kasnila s plaćanjem računa za režije, 62,0\% osoba koje žive u kućanstvima koja si ne mogu priuštiti tjedan dana godišnjeg odmora izvan kuće za sve članove svoga kućanstva, 12,8\% osoba žive u kućanstvima koja si ne mogu priuštiti obrok koji sadržava meso, piletinu, ribu (ili vegetarijanski ekvivalent) svaki drugi dan, 58,5\% osoba koje žive u kućanstvima koja ne mogu podmiriti neočekivani financijski izdatak iz vlastitih sredstava. Ako bismo dihotomizirali naše rezultate objedinivši kategoriju ponekad i često, možemo opet uočiti da je skupina obitelji koje smo kategorizirali da je u visokom riziku od siromaštva u uusvim aspektima u nepovoljnijem položaju od obitelji koje su u niskom riziku od siromaštva.
} 
obitelji. Tako se u obiteljima koje su u visokom riziku od siromaštva članovi nešto manje podržavaju, manje iskazuju ljubav i nježnost te se manje međusobno slušaju (razlike na razini $\mathrm{p}<0,05$ prisutne kod 3 od 12 tvrdnji).

Kao što se može vidjeti u tablici 1., rizik za zlostavljanje djece značajno je veći kod obitelji koje žive u riziku od siromaštva. To je u skladu s dosadašnjim nalazima istraživanja koja su koristila isti upitnik za mjerenje rizika za zlostavljanje djece i pokazala da su slabiji ekonomski status, odnosno manji prihodi, povezani s većim rizikom (Kalebić Jakupčević i Ajduković, 2011.; Benić, 2018.).

Komparativni model istraživanja omogućio nam je da provjerimo razliku u stupnju rizika za zlostavljanje djece kod majki prema visini prosječnog prihoda po članu obitelji. Rezultati na Inventaru rizičnosti za zlostavljanje trihotomizirani su po preporuci autora (Milner, 1986.) u kategoriju niskog rizika (rezultat manji od 166), umjerenog rizika (rezultat 166-214) i visokog rizika (rezultata 215 i više). Rezultati su prikazani u tablici 3., a razlike u distribuciji testirane su $\chi^{2}$ testom. uzorka na obitelji koje su u visokom riziku od siromaštva (sve obitelji čiji je prihod po članu obitelji manji od 1225 kuna nakon socijalnih transfera; prosjek po članu je u ovoj skupini obitelji 719,14 kuna) i niskom riziku od siromaštva (sve obitelji čiji je prihod po članu obitelji viši od 2400 kuna; prosjek po članu je u ovoj skupini obitelji 3 257,53 kuna $)^{4}$. U obiteljima koje žive u visokom riziku od siromaštva više je majki koje imaju umjereni i visoki rizik za zlostavljanje djece u odnosu na skupinu majki koje žive u obiteljima niskog rizika od siromaštva. Za razliku od kućanstava s višim prihodom gdje je nešto više od 15,7\% majki u kategoriji umjerenog i visokog rizika, u skupini s niskim prihodima gotovo $34,3 \%$ majki je u ovoj kategoriju. Razlika je pri tome najveća u skupini majki s visokim rizikom od siromaštva i čak 20,2\% tih majki je visoko rizična za zlostavljanje djece.

Ako usporedimo ove podatke s podacima prethodnih istraživanja provedenih u Hrvatskoj, možemo vidjeti da je rizik za zlostavljanje djece u obiteljima niskih prihoda znatno viši nego u uzorcima opće populacije. Tako su npr. u okviru epidemiološkog istraživanja izloženosti djece nasilju

Tablica 3.

Rizik za zlostavljanje djece kod majki u obiteljima visokog i niskog rizik od siromaštva

\begin{tabular}{|c|c|c|c|c|c|c|c|c|}
\hline \multirow{2}{*}{ Varijabla } & \multirow{2}{*}{$\begin{array}{l}\text { Rizik od } \\
\text { siromaštva }\end{array}$} & \multirow{2}{*}{$\mathrm{N}$} & Niski rizik & Umjereni rizik & Visoki rizik & \multirow{2}{*}{$\chi^{2}$} & \multirow{2}{*}{$p$} & \multirow{2}{*}{ V } \\
\hline & & & $\%$ & $\%$ & $\%$ & & & \\
\hline \multirow{2}{*}{$\begin{array}{l}\text { Rizik za zlostavljanje } \\
\text { djece }\end{array}$} & Visoki & 163 & 65,6 & 14,1 & 20,2 & \multirow{2}{*}{18,51} & \multirow{2}{*}{0,000} & \multirow{2}{*}{0,217} \\
\hline & Niski & 229 & 84,3 & 7,0 & 8,7 & & & \\
\hline
\end{tabular}

Rezultati pokazuju da postoji značajna razlika u distribuciji rizika za zlostavljanje djece majki prema prosječnom prihodu kućanstva. Podsjećamo da su ove razlike u prihodu korištene za podjelu početnog u obitelji u općoj populaciji, koristeći isti Inventar rizičnosti za zlostavljanje djece (Milner, 1986.), provedena dva istraživanja rizika za zlostavljanje djece - posebno za majke i posebno za očeve mlađih adolesce-

\footnotetext{
${ }^{4} \mathrm{U}$ tekstu ćemo iz stilskih razloga povremeno koristiti kao inačicu za obitelji u visokom riziku od siromaštva »obitelji s niskim prihodom« i za obitelji u niskom riziku od siromaštva kao inačicu »obitelji s višim prihodom«.
} 
nata. U istraživanju usmjerenom na majke (Sušac, Ajduković i Rajhvajn Bulat, 2015.) pokazalo se da je u općoj populaciji 11,0\% majki visokorizično, a 5,1\% u umjerenoj razini rizika za zlostavljanje djece (ukupno $16,1 \%$ majki je u riziku). U istraživanju Benić (2018.) koje je provedeno u dva vala, 2013. i 2016., pokazalo se da visoki rizik za zlostavljanje djece ima $6,5 \%$ očeva, a umjereni rizik 5,7\% očeva (ukupno 12,2\% očeva je u riziku za zlostavljanje djece). Dosadašnji podaci istraživanja provedenih u Hrvatskoj u skladu su s Milnerovim nalazima po kojem je stroži kriterij rizika za zlostavljanje djece definiran temeljem 5\% roditelja iz opće populacije koji iskazuju najveći rezultat. Rezultati o visokom riziku za zlostavljanje djece su u ovom istraživanju nešto viši i za majke iz obitelji u niskom riziku od siromaštva $(8,7 \%)$ dok za majke u visokom riziku od siromaštva dosežu iznimno visoki postotak od čak 20,2\% majki, odnosno svaka 5 majka iz ove skupine je visoko rizična za zlostavljanje djece.

\section{Doprinos objektivnih i subjektivnih pokazatelja socioekonomskog statusa kvaliteti obiteljskog funkcioniranja i riziku za zlostavljanje djece u obiteljima izloženim visokom i niskom riziku od siromaštva s posebnim osvrtom na ulogu socijalne podrške}

Kako bi se ispitao doprinos objektivnih i subjektivnih pokazatelja socioekonomskog statusa kvaliteti obiteljskog funkcioniranja i riziku za nasilje nad djecom u obiteljima izloženim visokom i niskom riziku od siromaštva, provedeno je šest regresijskih analiza. Za svaki kriterij provedene su usporedne regresijske analize za obitelji s niskim prihodima i visokim rizikom od siromaštva $\left(\mathrm{N}_{\text {visoki }}=163\right)$ i obiteljima s višim prihodima i niskom riziku od siromaštva $\left(\mathrm{N}_{\text {niski }}=229\right)$. Prije provođenja hijerarhijske regresijske analize (HRA) provjerili smo korelacije među prediktorima i korelacije prediktora i kriterija (prikazano u tablici 4.).

Kao što se može vidjeti, kriterijske varijable su međusobno srednje visoko povezane. Tako je kod obitelji koje su u visokomuu riziku od siromaštva rizik za zlostavljanje djece negativno povezan s bliskosti u obiteljskim odnosima $(\mathrm{r}=-0,551 ; \mathrm{p}<0,01)$, a pozitivno povezan $\mathrm{s}$ konfliktima u obitelji (r $=0,558 ; \mathrm{p}<0,01)$. Što se tiče prediktorskog sklopa, rizik za zlostavljanje djece najviše je povezan sa subjektivnom mjerom ekonomskih teškoća, odnosno s većom posramljenosti majke zbog financijske situacije $\mathrm{u}$ obitelji $(\mathrm{r}=0,523 ; \mathrm{p}<0,001)$, većim brojem stresnih događaja $(r=0,510 ; p<0,001)$, nepovoljnim učinkom financijskih teškoća na odnose u obitelji $(r=0,481 ; p<0,001)$ i s većom materijalnom deprivacijom obitelji $(r=-0,353 ; p<0,001)$. Što je manja socijalna podrška, veći je rizik za zlostavljanje djece $(\mathrm{r}=-0,369 ; \mathrm{p}<0,001)$.

Kod obitelji koje su u niskom riziku od siromaštva povezanosti su vrlo slične. Tako je rizik za zlostavljanje djece negativno povezan s bliskosti u obiteljskim odnosima ( $\mathrm{r}$ $=-0,572 ; \mathrm{p}<0,001)$, a pozitivno povezan $\mathrm{s}$ konfliktima u obitelji $(r=0,553$; $p<0,001)$. Što se tiče prediktorskog sklopa, korelacije s kriterijskom varijablom rizika za zlostavljanje djece su nešto niže osim za socijalnu podršku, a najveća je povezanost sa subjektivnom mjerom ekonomskih teškoća, odnosno s većom posramljenosti majke zbog financijske situacije $\mathrm{u}$ obitelji $(\mathrm{r}=0,523$; $\mathrm{p}<0,01)$, većim brojem stresnih događaja $(\mathrm{r}=0,510 ; \mathrm{p}<0,01)$, nepovoljnim učinkom financijskih teškoća na odnose u obitelji (r $=0,481 ; \mathrm{p}<0,01)$ i s većom materijalnom deprivacijom obitelji $(r=-0,353 ; p<0,01)$. Što je manja socijalna podrška, veći je rizik za zlostavljanje djece $(r=-0,369 ; \mathrm{p}<0,01)$.

U tablicama 5., 6. i 7. prikazani su standardizirani ponderi usporednih regresijskih analiza. U tekstu koji slijedi koristit ćemo povremeno kraticu VRS za obitelji visokog 


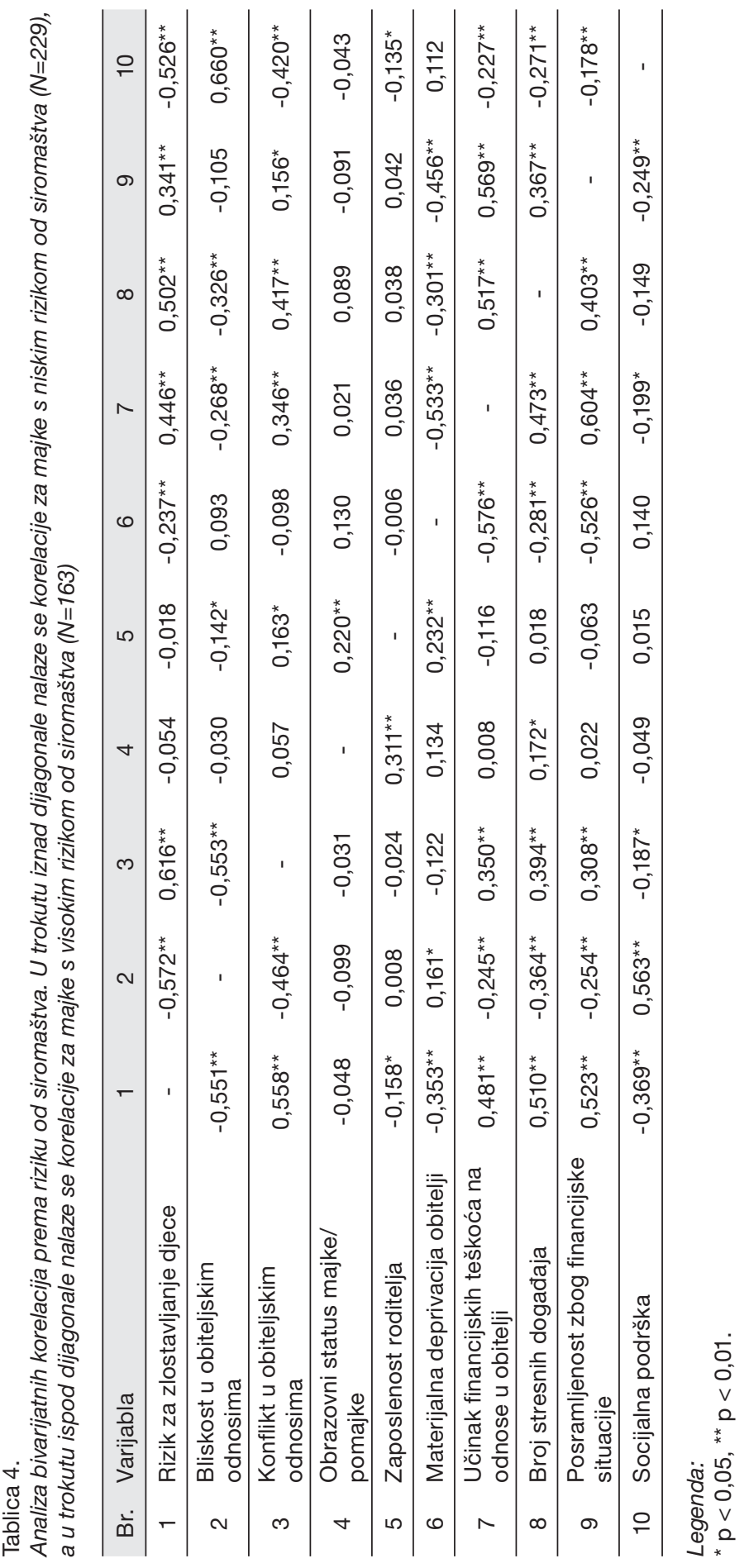


rizika od siromaštva i kraticu NRS za obitelji niskog rizika od siromaštva. Za sva tri kriterija - bliskost i konflikti u obitelji, te rizik za zlostavljanje djece - HRA je provedena u četiri koraka. U prvom koraku su objektivni pokazatelji socioekonomskog statusa obitelji opisani obrazovnim statusom majke i zaposlenosti roditelja. U drugom koraku je razina materijalne deprivacije obitelji i učinak financijske situacije na odnose u obitelji, kao subjektivne mjere doživljenog ekonomskog pritiska na obitelj. U trećem koraku su varijable koje se odnose na broj stresnih događaja kojima je izložena obitelj te na psihološki stres operacionaliziran kroz osjećaj posramljenosti zbog financijske situacije u obitelji. U posljednjem, četvrtom, koraku je samo socijalna podrška. Naime, polazeći od nalaza većeg brojnih istraživanja (npr. Ceballo i McLoyd, 2002.; Lee, Anderson, Horowitz i August, 2009.; Kalebić Jakupčević i Ajduković, 2011.; Lee i Lee, 2016; Ajduković i sur., 2018.), željeli smo provjeriti koji je u konačnici doprinos socijalne podrške umanjivanju negativnih učinaka obiteljskih okolnosti vezanih uz materijalni status i izloženost obitelji stresnim događajima na kvalitetu obiteljskog funkcioniranja i roditeljstvo.

Kao što se može vidjeti u tablicama 5. do 7., prediktorski sklop najbolje objašnjava rizik za zlostavljanje djece (47\% objašnjene varijance i za majke VRS i NRS) i bliskost u obitelji (40\% objašnjene varijance za majke VRS i 48\% NRS), dok slabije objašnjava konflikte u obiteljskim odnosima $(23 \%$ objašnjene varijance za obitelji u VRS-u i $32 \%$ za obitelji u NRS-u). Posebno su zanimljivi rezultati za područje bliskosti kao kvalitete obiteljskog funkcioniranja. U prva tri koraka HRA, bliskost je negativno povezana sa zaposlenosti roditelja, ali samo kod majki NRS, odnosno njihova nezaposlenost povezana je s njihovim manjim doživljajem bliskosti u obitelji. Uvođenjem socijalne podrške u četvrtom koraku, gubi se učinak zaposlenosti na kvalitetu bliskosti u obitelji kod majki NRS. Kod majki NRS procjena financijskih teškoća na odnose u obitelji je značajan prediktor doživljaja bliskosti i u drugom, trećem i četvrtom koraku. No, uvođenjem socijalne podrške vidno se smanjuje i učinak financijskih teškoća na odnose u obitelji koji ostaje značajan, ali nizak negativni prediktor bliskosti u obitelji $(\beta=$ $-0,150, p<0,05)$ samo kod obitelji niskog rizika od siromaštva. Dakle, što je manji učinak financijskih teškoća na odnose u obitelji, veća je bliskost kod obitelji NRS. Za majke NRS uvođenjem socijalne podrške vidno se smanjuje i učinak broja stresnih događaja, dok kod majki VRS socijalna podrška dovodi do tek neznatnog negativnog prediktivnog značaja broja stresnih događaja u obitelji, te je u zadnjem koraku $\beta=-0,276(p<0,01)$ za obitelji VRS i $\beta=$ $-0,147(\mathrm{p}<0,05)$ za obitelji u NRS-u. I kod jednih i kod drugih obitelji veća bliskost je u obiteljima koje su izložene manjem broju stresnih događaja.

Kod konflikata kao dimenzije kvalitete obiteljskog funkcioniranja socijalna podrška nema toliki značaj, štoviše, kod obitelji s VRS-om nije uopće značajan prediktor. Kod ovih obitelji značajni prediktori u posljednjem koraku su materijalna deprivacija obitelji $(\beta=0,187, p<0,05)$, učinak financijskih teškoća na odnose u obitelji $(\beta=0,218$, $\mathrm{p}<0,05)$ te broj stresnih događaja $(\beta=0,294$, $\mathrm{p}<0,01)$. Kao što možemo vidjeti, radi se o subjektivnim teškoćama vezanim uz doŽivljaj niskih prihoda i izloženosti većem broju stresnih događaja. Kod obitelji NRS značajni prediktori konflikata su negativni učinak financijskih teškoća na odnose u obitelji $(\beta=0,244, p<0,01)$, broj stresnih događaja kojima je obitelj bila izložena $\mathrm{u}$ proteklom razdoblju $(\beta=0,277, \mathrm{p}<0,01)$, te veća zaposlenost roditelja $(\beta=0,115$, $\mathrm{p}<0,05)$. Iako se radi o niskoj prediktivnoj vrijednosti, ovaj nalaz upućuje da bi zaposlenost oba roditelja mogla pridonositi konfliktima u obitelji ne zbog materijalnih razloga, već, po svemu sudeći, poteškoća u 


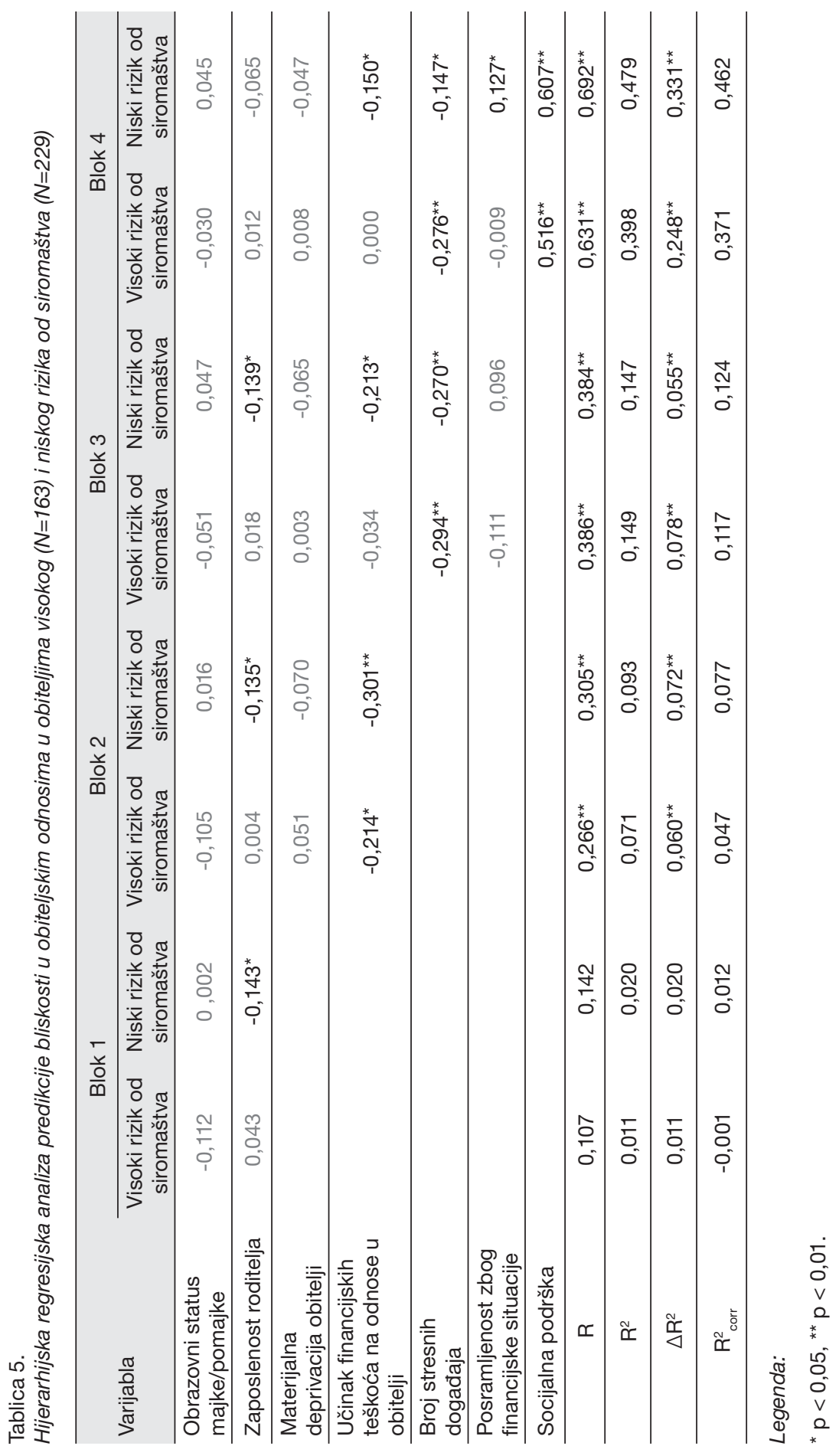




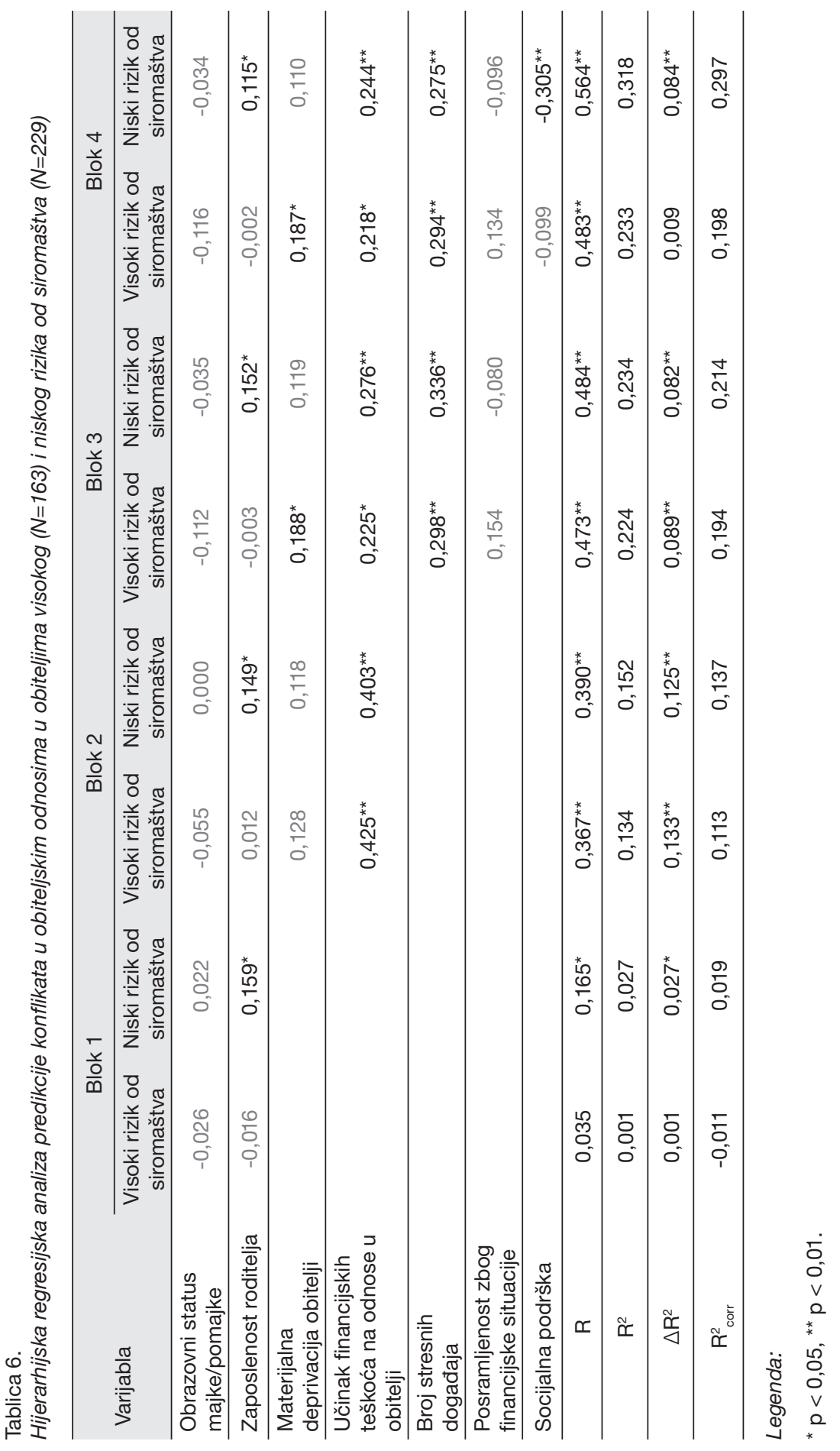




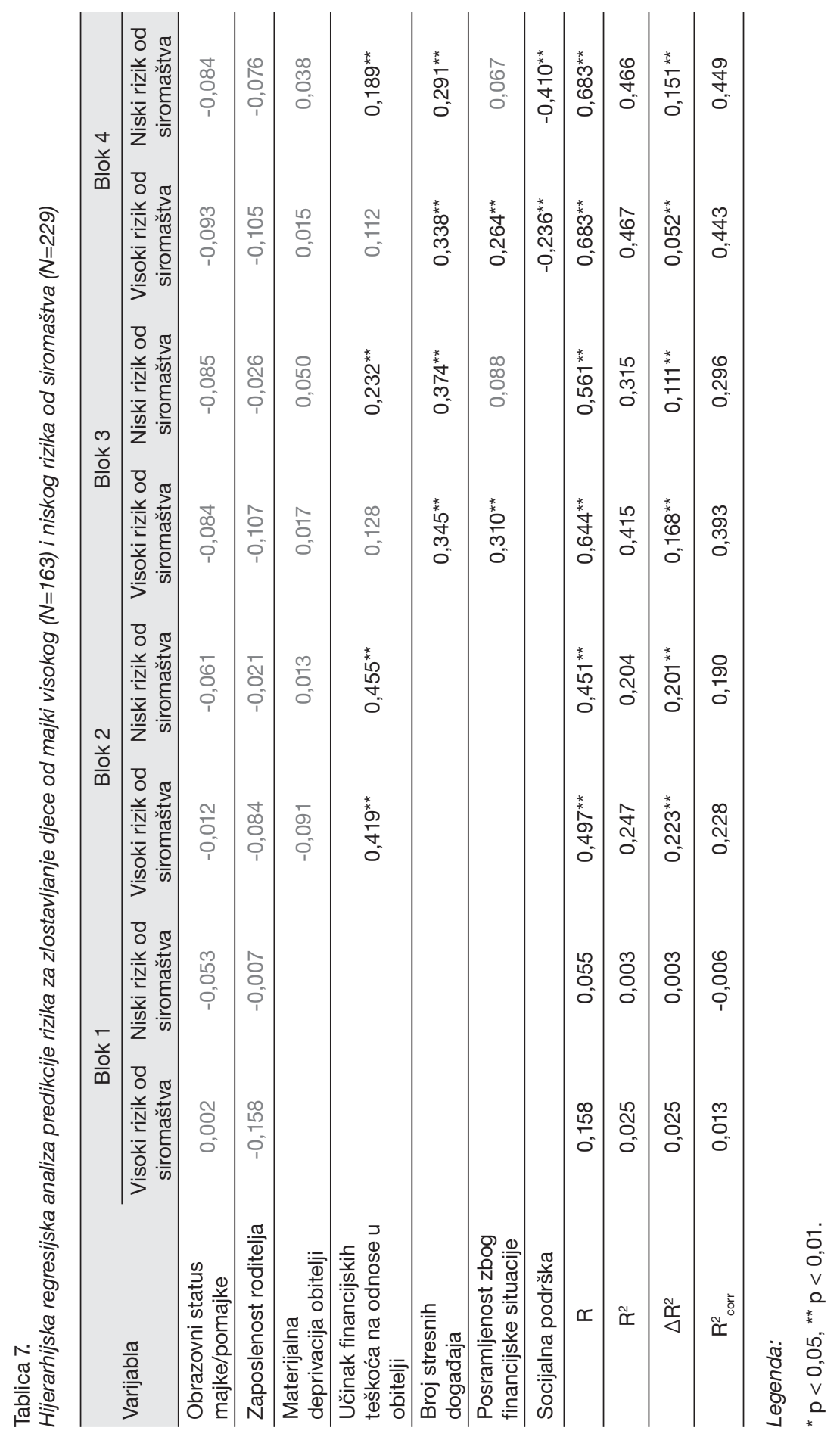


balansiranju radne i ostalih uloga u obitelji. Na to upućuje i podatak o negativnoj povezanost između zaposlenosti oba roditelja i bliskosti u odnosima u obiteljima NRS ( $\mathrm{r}=$ $-0,142 ; \mathrm{p}<0,05)$. Iako se radi o niskoj korelaciji, odnos između zaposlenost, bliskosti i konflikata u obiteljima s djecom NRS bi mogao biti u fokusu nekih daljnjih istraživanja. Što se tiče ove skupine obitelji, konfliktna dimenzija kvalitete je manja ako je percipirana socijalna podrška veća $(\beta=$ $-0,305 ; \mathrm{p}<0,01)$.

Što se tiče rizika za zlostavljanje djece, postotak objašnjene varijance opisanim prediktorskim skupom, kao što smo već naveli, identičan je za obje skupine roditelja i iznosi relativno visokih $47 \%$ objašnjene varijance. Ono što je različito je doprinos pojedinih prediktora. Niti u jednom koraku nisu se pokazali kao značajni prediktori objektivni pokazatelji socioekonomskog statusa obitelji. U drugom koraku kod obje skupine obitelji kao značajan prediktor pokazao se učinak financijskih poteškoća na odnose u obitelji, no u zadnjem, četvrtom, koraku to je ostao kao značajni prediktor samo kod obitelji s NRS-om. U zadnjem koraku broj stresnih događaja kojem je izložena obitelj je značajan prediktor za obje skupine obitelji, kao i izostanak socijalne podrške. No, tu se može uočiti razlika u prediktivnom značaju između ovih obitelji. Vidljivo je da je ovako koncipirana socijalna podrška važnija za umanjivanje rizika za zlostavljanje djece kod majki iz obitelji s NRS ( $\beta=$ $-0,410 ; \mathrm{p}<0,01)$ nego kod majki iz obitelji s VRS-om $(\beta=-0,236 ; p<0,01)$. No, kod ove skupine majki javlja se kao značajni prediktor rizika za zlostavljanja djece posramljenost zbog financijske situacije obitelji ( $\beta=$ 0,264; $\mathrm{p}<0,01)$.

U cjelini, ovi podaci pokazuju da, iako je nakon socijalnih transfera rizik za zlo- stavljanje djece statistički značajno veći kod majki iz obitelji s VRS-om, značajni prediktori su posramljenost zbog financijske situacije i izloženost većem broju stresnih događaja. Socijalna podrška, iako je značajni prediktor, ima vidljivo manju snagu nego kod majki obitelji s NRS-om. Polazeći od navedenog, u raspravi će se dodatno produbiti značaj izloženost stresnim događajima i specifičnost potrebne socijalne podrške kod majki iz obitelji s VRS-om.

\section{RASPRAVA}

Provedene analize pokazale su da subjektivni i objektivni pokazatelji financijske situacije u obitelji imaju učinak kako na kvalitetu obiteljskih odnosa, tako i na roditeljstvo. Očekivano negativni učinak financijskih teškoća na odnose u obitelji smanjuje bliskost i to samo kod obitelji niskog rizika od siromaštva. Istodobno i kod obitelji VRS i NRS veća bliskost je u obiteljima koje su izložene manjem broju stresnih događaja. Što se tiče konflikata u obitelji, njihovi značajni prediktori u obiteljima koje su u VRS-u su materijalna deprivacija obitelji i negativni učinak financijskih teškoća na odnose u obitelji, te broj stresnih događaja. Kod obitelji u NRS-u značajni prediktori konflikata su negativni učinak financijskih teškoća na odnose u obitelji, broj stresnih događaja te veća zaposlenost roditelja ( $\beta=$ $0,115, \mathrm{p}<0,05)$.

Kod konflikata kao dimenzije kvalitete obiteljskog funkcioniranja socijalna podrška nema toliki značaj, štoviše, kod obitelji s VRS-om nije uopće značajan prediktor. Istodobno, socijalna podrška ima daleko najveću prediktivnu vrijednost za bliskost kao kvalitetu obiteljskog funkcioniranja. Ako pogledamo upitnike kojima su ispitivani ovi konstrukti, ovaj nalaz ne iznenađuje ${ }^{5}$.

\footnotetext{
${ }^{5}$ Tvrdnje u Upitnika socijalne podrške su npr. »Imam prijatelje s kojima mogu dijeliti sreću i tugu.«; »Sa svojim prijateljima mogu razgovarati o svojim problemima. «, »Od svoje obitelji dobivam emocionalnu pomoć i podršku koja mi treba.«, »Moja obitelj mi je voljna pomoći u donošenju odluka.«.
} 
Opravdano možemo očekivati da pojedinci koji pridonose bliskosti u svom obiteljskom okruženju imaju i veći kapacitete da traže i dobiju socijalnu podršku kako u svojoj obitelji tako i u svojoj široj socijalnoj mreži. Nasuprot tome, kod konflikata kao dimenzije kvalitete obiteljskog funkcioniranja socijalna podrška nema toliki značaj, što više kod obitelji s VRS-om nije uopće značajan prediktor. Moguće je da kapacitete obitelji za konstruktivno rješavanje sukoba u takvim situacijama iscrpljuje ekonomska situacija i standardni oblici socijalne podrške to ne mogu olakšati.

Ako pogledamo nalaze o kvaliteti odnosa u obitelji, u cjelini možemo uočiti da je ovisno o tome nalaze li se obitelji u visokom ili niskom riziku od siromaštva, pojedini subjektivni aspekti ekonomskog pritiska i objektivni aspekti socioekonomskog statusa imaju različiti prediktivni značaj, te da socijalna podrška ima vidno manji značaj za kvalitetu odnosa u obiteljima NRS. To upućuje da je i u daljnjim istraživanjima kvalitete obiteljskih odnosa potrebno i dalje razvijati i koristiti i objektivne i subjektivne pokazatelje financijske situacije obitelji, te da je potrebno istražiti koji su to zaštitni mehanizmi osim standardno mjerene socijalne podrške koji mogu imati protektivni učinak na kvalitetu odnosa u obiteljima koje su suočene s ozbiljnim financijskim teškoćama.

Podatak da je kod majki u obiteljima koje žive u visokom riziku od siromaštva njih $20,2 \%$ visoko rizično za zlostavljanje djece jasno upućuje na potrebu da se ovim majkama pruži odgovarajuća podrška u roditeljstvu. To što se radi o riziku za zlostavljanje, a ne nužno o fizičkom kažnjavanju ili zlostavljanju djece, ne umanjuje potrebu integriranog pristupa ovim obiteljima u cilju prevencije ili/i zaustavljanja nasilja nad djecom. Upravo suprotno, ova razina rizika stavlja dodatnu odgovornost na stručnjake da prepoznaju obitelji koje su u riziku za zlostavljanje djece prije nego dođe do eska- lacije nasilnih odgojnih postupaka i da im pruže odgovarajuću potporu. U trenutno ključnom dokumentu za zaustavljanju nasilja nad djecom INSPIRE: Seven strategies for ending violence against children (WHO, 2016.) upravo je područje prihoda i ekonomskog osnaživanje obitelji naglašeno kao jedna od ključnih strategija. Uz povećanje materijalnih oblika pomoći ovim roditeljima nužno je pokrenuti razgovor o izazovima roditeljstva i načinima rješavanja sukoba u obitelji te omogućiti odgovarajuće oblike psihosocijalne podrške (npr. uključivanje u programe pozitivnog nenasilnog roditeljstva). Pri tome sustav socijalne skrbi ima ključnu ulogu da s obiteljima koje su korisnici različitih oblika potpore pokrene razgovor o izazovima roditeljstva u situaciji visoke razine ekonomskog $\mathrm{i}$ životnog stresa.

U skladu s dosadašnjim istraživanjima (npr. Bishop i Leadbeater, 1999.; Tucker i Rodriguez, 2014.), i u našem istraživanju pokazalo se da je percipirana socijalna podrška negativno povezana s rizikom za zlostavljanje djece. Pri tome je specifičan doprinos ovog istraživanja što je pokazalo da je zaštitni učinak socijalne podrške, iako statistički značajan, niži kod majki koje žive u visokom riziku od siromaštva. Istodobno, ove majke pokazuju značajno veći rizik za zlostavljanja djece te je iznimno značajno istražiti koji bi dodatni resursi, uključujući specifične oblike socijalne (i druge) podrške, bili čimbenici zaštite od nasilja nad djecom u obiteljima u visokom riziku od siromaštva.

Socijalna podrška pokazala se kao jedan od ključnih zaštitnih čimbenika koji ublažava utjecaj negativnih životnih okolnosti na roditeljstvo u različitim uzorcima opće populacije majki. Tako su npr. Raboteg-Šarić i Pećnik (2006.) pokazale kako su različiti aspekti socijalne podrške na različite načine povezani s dimenzijama roditeljskih odgojnih postupaka. Tako instrumentalna puodrška okoline pridonosi većoj podršci 
roditelja djetetu, nadzoru i zajedničkom odlučivanju s djecom, a podrška prijatelja roditeljskoj uključenosti u odgoj djece. Uz to, podrška prijatelja i instrumentalna podrška djeluju kao moderatori negativnog utjecaja financijskoga stresa i depresivnosti roditelja na roditeljski nadzor.

No, tek mali broj istraživanja bio je usmjeren na specifične učinke socijalne podrške na roditeljstvo u obiteljima koje su siromašne i žive u siromašnijim sredinama (Ceballo i McLoyd, 2002.). Tek su nove studije usmjerene na načine na koji su roditeljski resursi povezani sa smanjenim rizikom za zlostavljanje djece te uključuju interakciju socijalne podrške s drugim čimbenicima. Tako su Tucker i Rodriguez (2014.) pokazali da socijalna izolacija moderira odnos kumulativnog stresa i zlostavljanja djece. Konkretno, majke koje su bile izložene i višoj razini kumulativnog stresa i socijalnoj izolaciji pokazale su veći rizik za zlostavljanje djece od majki koje su bile izložene samo višoj razini stresa ili samo socijalnoj izolaciji. Ranije studije s roditeljima niskih prihoda pokazale su da socijalna podrška nije povezana s manjim roditeljskim stresom i da ne moderira odnos između prihoda i roditeljskog stresa (Raikes i Thompson, 2005.). Ceballo i McLoyd (2002.) pokazali su da je pozitivan učinak socijalne podrške na roditeljska ponašanja umanjen u siromašnijim obiteljima.

Nekoliko hipoteza može objasnite ove nalaze po kojima je učinak standardno mjerene socijalne podrške na smanjivanje rizika za zlostavljanje djece manji u obiteljima koje žive u visokom riziku od siromaštva. Jedna je da uobičajeni mehanizmi socijalne podrške u siromašnim obiteljima ne mogu dovoljno kompenzirati negativne učinke siromaštva u interakciji s drugim stresorima. Druga hipoteza je da je u situacijama dugoročnih ekonomskih kriza, kao što je to slučaj u Hrvatskoj, dostupnost podrške siromašnim obiteljima manja jer je iscr- pljena i prirodna socijalna mreža podrške, a istodobno su i nedovoljni društveni resursi, uključujući resurse profesionalne zajednice. Treća je hipoteza da visoka razina izloženosti kumulativnom učinku životnih stresora može dovesti do smanjenja percepcije socijalne podrške. U prilog prve dvije hipoteze idu nalazi istraživanja Stubbsa i sur. (2017.) provedenog u kućanstvima korisnika zajamčene minimalne naknade u kojima je barem jedan član obitelji dijete. Pokazalo se da se siromašne obitelji kad im je potreban novac najčešće obraćaju obitelji i rodbini $(41,5 \%)$, zatim prijateljima $(24,2 \%)$, pa CZSS-u $(23,7 \%)$, a $8,7 \%$ se ne obraća nikome. Pri tome, navode da je upravo CZSS mjesto na kojem mogu najviše računati na pomoć, više nego od bližnjih, susjeda ili ostalih institucija.

Polazeći od svega navedenog, nužna su daljnja kvalitativna istraživanja koja bi omogućila produbljeni uvid s jedne strane $\mathrm{u}$ dostupnost, a s druge strane u poželjne oblike kako instrumentalne tako i emocionalne podrške obiteljima s djecom koje žive u visokom riziku od siromaštva. Pri tome bi bilo nužno usmjeriti se na oblike socijalne i ostale podrške koje te obitelji trebaju u području roditeljstva. Temeljem takvih istraživanja bi se mogle dalje razvijati mjere socijalne politike $\mathrm{i}$ intervencije usmjerene na ciljano povećanje socijalne (i ostale) podrške roditeljima koji žive u siromaštvu i/ili visokom riziku od siromaštva. To bi značilo da se djelovanje ne usmjeri samo na negativne ishode siromaštva na roditeljstvo, kao što je npr. veći rizik za zlostavljanje djece, već i na okolnosti koje tome pridonose.

Nalazi ovog istraživanja idu u prilog dosljednom naglašavanju empirijski utemeljenih smjernica da je, između ostaloga, smanjivanje siromaštva nužno za djelotvorno smanjivanje nasilja nad djecom (Sethi i sur., 2013.; WHO, 2016.) te da treba pažljivo i na odgovarajući način planirati mjere 
upravo za one koje su u najvećem riziku od siromaštva. U prilog tome idu i nalazi dva iznimno relevantna istraživanja koja nam dolaze iz različitih istraživačkih diskursa. Tako su Cancian, Yang i Slack (2013.) u eksperimentalnom istraživanju provedenom s velikim uzorkom od čak 13000 kućanstava samohranih majki »u prirodnim uvjetima« pokazali da tek nešto viša financijska pomoć značajno smanjuje rizik za nasilje nad djecom. Konkretno, majke koje su kao dio eksperimentalne intervencije dobile u prosjeku za uzdržavanje djece dodanih $102 \$$ u odnosu na zagarantiranih $755 \$$ su tijekom dvogodišnjeg praćenje službenih podataka nadležnih službi značajno rjeđe bile prijavljivane i procjenjivane zbog nasilja nad djecom. Kao što autori navode, relativno skromna razlika u dohotku mogla bi smanjivati rizik za zlostavljanje djece te je to posebno značajno za one koji su siromašniji. Naglašavaju važnost rasprave o potrebi za darežljivijom financijskom podrškom koja bi upravo kod najsiromašnijih obitelji smanjila rizik za zlostavljanje djece. U prilog tome da bi se upravo najsiromašnijima trebalo dati više financijske podrške idu i već spomenuti nalazi istraživanju Noble i sur. (2015.) koji su pokazali da je veza prihoda i razvoja prefrontalnog korteksa najvidljivija kod djece u najnepovoljnijim ekonomskim situacijama.

Ovo istraživanje ima i nekoliko ograničenja. Kao prvo, transverzalni nacrt ne omogućava zaključivanje o uzročno-posljedičnim odnosima, pa se o značenju prediktora može samo teoretski zaključiti.

Uz to, istraživanje se oslanja na samoprocjene, koje su podložne pristranosti i socijalnoj poželjnosti. Tako se npr. raspodjele sudionica istraživanja u dvije grupe - grupu NRS i VRS - temeljila na njihovom samoiskazu o prihodu domaćinstva gdje je moguće da je došlo kako do precjenjivanja, tako i do umanjivanja ukupnog prihoda domaćinstva. No, kao što je dobro poznato, mjere sa- moprocjene su u širokoj upotrebi u ovakvim istraživanjima, pogotovo kada informacije nisu lako dostupne na drugi način.

Kako su rezultati istraživanje pokazali, Skala percipirane socijalne podrške (MSPSS) koja se inače široko koristi u istraživanjima, pokazala se boljom za predikciju kriterijskih varijabli u skupini obitelji NRS. Po svemu sudeći, za procjenu značaja socijalne podrške kod obitelji VRS potrebno je koristiti skale koje bolje mjere emocionalnu i instrumentalnu podršku. Primjer takve višedimenzionalne skale socijalne podrške je Ljestvica percipirane socijalne podrške (Simons i sur., 1996., prema Raboteg-Šarić i Pećnik, 2006.). Raboteg-Šarić i Pećnik (2006.) potvrdile su prednosti takvih višedimenzionalnih skala socijalne podrške kao čimbenika zaštite $u$ istraživanjima roditeljstva.

Unatoč ovim ograničenjima, rezultati ovog istraživanja pokazali su koliko je metodološki značajno u prediktorskom sklopu uz standardne mjere socioekonomskog statusa, koristiti i različite subjektivne mjere ekonomskog pritiska koje doživljavaju članovi obitelji, u ovom slučaju majke.

\section{ZAKLJUČAK}

Cilj ovog istraživanja bio je ispitati doprinos objektivnih i subjektivnih pokazatelja socioekonomskog statusa, izloženosti stresnim događajima i dostupnosti socijalne podrške kvaliteti obiteljskih odnosa i riziku za zlostavljanje djece kod majki adolescenata u obiteljima izloženim visokom i niskom riziku od siromaštva.

Usporedba kvalitete obiteljskog funkcioniranja i rizičnosti za zlostavljanje nad djecom u obiteljima izloženim visokom i niskom riziku od siromaštva, pokazala je da, u skladu s Congerovim modelom obiteljskog stresa, u obiteljima koje su u visokom riziku od siromaštva konflikti u obitelji i rizik majki za zlostavljanje djece statistički 
su značajno češći u odnosu na obitelji koje su u niskom riziku od siromaštva. Ove dvije skupine ne razlikuju se značajno s obzirom na stupanj bliskosti među članovima. Što se tiče konflikata kao dimenzije kvalitete obiteljskog funkcioniranja, kod obitelji s VRS-om značajni prediktori su materijalna deprivacija obitelji, nepovoljni učinak financijskih teškoća na odnose u obitelji te veći broj stresnih događaja. Kod obitelji NRS značajni prediktori konflikata su negativni učinak financijskih teškoća na odnose u obitelji, veći broj stresnih događaja kojima je obitelj bila izložena u proteklom razdoblju te, neočekivano, zaposlenost roditelja.

Prediktori rizika za zlostavljanje adolescenata u obiteljima su, i za jednu i za drugu skupinu obitelji, broj stresnih događaja kojem je izložena obitelj i izostanak socijalne podrške. Pri tome je dostupnost socijalne podrške važnija za umanjivanje rizika za zlostavljanje djece kod majki iz obitelji s NRS-om nego kod majki iz obitelji s VRSom. Kod ove skupine majki javlja se kao značajni prediktor rizika za zlostavljanja djece posramljenost zbog financijske situacije obitelji. Ovi nalazi otvorili su pitanje koji oblici instrumentalne i emocionalne podrške bi bili potrebni obiteljima s djecom koje žive u visokom riziku od siromaštva kako bi se smanjio njihov rizik za nasilja nad djecom, odnosno kako bi se povećao njihov kapacitet za nenasilno roditeljstvo.

Rasprava rezultata otvorila je pitanje kako se u Hrvatskoj vodi računa o suvremenim spoznajama pri planiranju mjera koje trebaju olakšati život djece u siromašnim obiteljima. Ilustrirat ćemo to jednim primjerom. Zakon o izmjenama i dopunama Zakona o doplatku za djecu koji je stupio na snagu 1. srpnja 2018. povećat će broj korisnika dječjeg doplatka, no neće povećati njegovu visinu za najugroženije skupine što bi polazeći od suvremenih istraživanja bilo nužno (Cancian, Yang i Slack, 2013.; Noble i sur., 2015.). Hoće li i koliki će učinak ove promjene Zakona o doplatku za djecu imati na demografsku sliku Hrvatske pokazat će vrijeme, no ono što je nedvojbeno je da su najsiromašnija djeca opet ostavljena po strani. Pod tim vidom, treba čim prije staviti na javnu raspravu ideju da se uvede, kao što predlažu Stubbs i sur. (2017.), dodatni, ciljani doplatak za djecu u kućanstvima s najnižim prihodima. To bi bio mali, ali nužni doprinos daljnjem razvoju koherentne i fleksibilne socijalne politike umjerene na umanjivanje društveno-ekonomskih rizika uz istodobno jačanje podrške obitelji i promicanje učinkovitih strategija roditeljstva (McConnell, Breitkreuz i Savage, 2010.) koje bi omogućile prilagodbu intervencija intenzitetu i obilježjima siromaštva vodeći računa o višestrukim dimenzijama siromaštva (WHO, 2016.).

\section{LITERATURA}

Ajduković, M., \& Rajter, M. (2014). Obiteljski ekonomski stres kao čimbenik rizika za nasilne odgojne postupke i psihosocijalnu dobrobit djece. U A. Brajša-Žganec, J. Lopižić \& Z. Penezić (ur.), Psihološki aspekti suvremene obitelji, braka $i$ partnerstva (str. 353-375). Jastrebarsko: Naklada Slap, Hrvatsko psihološko društvo.

Ajduković, M., \& Rimac, I. (2017). Kako prekinuti začarani kruga siromaštva djece? Razlozi, polazišta i ciljevi istraživanja dobrobiti i siromaštva djece u Hrvatskoj. Ljetopis socijalnog rada, 24(2), 193-198. https://hrcak.srce.hr/192736

Ajduković, M., Dobrotić, I., \& Matančević, J. (2017). Mogućnosti unapređenja socijalne politike u smanjivanju siromaštva djece: Perspektiva ključnih dionika. Ljetopis socijalnog rada, 24(2), 309356. https://hrcak.srce.hr/192740

Ajduković, M., Družić Ljubotina, O., \& Kletečki Radović, M. (2016a). Upitnik materijalne deprivacije. Neobjavljeni materijal.

Ajduković, M., Družić Ljubotina, O., \& Kletečki Radović, M. (2016b). Upitnik suočavanja s ekonomskim teškoćama obitelji. Neobjavljeni materijal.

Ajduković, M., Rajter, M., \& Rezo, I. (2017). Predicting child abuse potential: The role of social support in times of economic hardship. In Book of Abstracts: The 15th European Conference on Traumatic Stress: Child Maltreatment Across the Lifespan (pp. 116-116). Odense. 
Ajduković, M., Rajter, M., \& Sušac, N. (2011). Upitnik svakodnevnog stresa i doživljenih stresora. Neobjavljeni materijal.

Anđelinović, M., Merkaš, M., Brdovčak, B., \& Matijaš, M. (2017). Povezanost ekonomske prilagodbe obitelji i zadovoljstva životom kod djece: uloga depresivnosti roditelja i roditeljske samoefikasnosti. U L. Arambašić, I. Erceg \& Ž. Kamenov (ur.), 23. Dani Ramira i Zorana Bujasa - Knjiga sažetaka (str. 216-216). Zagreb: Medicinska naklada.

Anđelinović, M., Vrselja, I., Merkaš, M., \& Pandžić, M. (2016). Uloga roditeljske depresivnosti i kompetentnosti u odnosu između ekonomske prilagodbe obitelji i depresivnosti adolescenata. U A. Pokrajac-Bulian, I. Miletić, J. Juretić \& J. Lopižić (ur.), Knjiga sažetaka 24. godišnje konferencije hrvatskih psihologa »Psihologija $u$ prevenciji poremećaja i očuvanju zdravlja« (str. 78-78). Opatija: Hrvatsko psihološko društvo.

Babić, Z. (2013). Ekonomski aspekti ulaganja u rani razvoj djece: Komparativni prikaz. U N. Pećnik (ur.), Kako roditelji i djeca brinu o djeci najmlađe dobi u Hrvatskoj. Zagreb: Ured UNICEF-a za Hrvatsku.

Bagić, D., Dobrotić, I., Lažnjak, J., Rodik, P., \& Vučković Juroš, T. (2017). Coping strategies of economically (partially) inactive households: The case of Croatia. Südosteuropa, 65(3), 542-564. https://doi.org/10.1515/soeu-2017-0034

Benić, M. (2018). Prediktori potencijala za zlostavljanje kod očeva djece starijeg osnovnoškolskog uzrasta (magistarski rad). Univerzitet u Beogradu, Filozofski fakultet.

Bishop, S. J., \& Leadbeater, B. J. (1999). Maternal social support patterns and child maltreatment: Comparison of maltreating and nonmaltreating mothers. American Journal of Orthopsychiatry, 69(2), 172-181. https://doi.org/10.1037/ h0080419

Cancian, M., Yang, M. Y., \& Slack, K. S. (2013). The effect of additional child support income on the risk of child maltreatment. Social Service Review, 87(3), 417-437. https://doi. org/10.1086/671929

Ceballo, R., \& McLoyd, V. C. (2002). Social support and parenting in poor, dangerous neighborhoods. Child Development, 73(4), 1310-1321. https://doi.org/10.1111/1467-8624.00473

Conger, K. J., Rueter, M. A., \& Conger, R. D. (2000). The role of economic pressure in the lives of parents and their adolescents: The Family Stress Model. In L. J. Crockett \& R. K. Silbereisen (Eds.), Negotiating adolescence in times of so- cial change (pp. 201-223). New York: Cambridge University Press.

Dew, J., \& Yorgason, J. (2010). Economic pressure and marital conflict in retirement-aged couples. Journal of Family Issues, 31(2), 164-188. https://doi.org/10.1177/0192513X09344168

Donnellan, M. B., Conger, K. J., McAdams, K. K., \& Neppl, T. K. (2009). Personal characteristics and resilience to economic hardship and its consequences: Conceptual issues and empirical illustrations. Journal of Personality, 77(6), 1645-1676. https://doi.org/10.1111/ j.1467-6494.2009.00596.x

Državni zavod za statistiku. (2016). Statistički ljetopis Republike Hrvatske. Dostupno na https:// www.dzs.hr/Hrv_Eng/ljetopis/2016/sljh2016.pdf

Kalebić Jakupčević, K., \& Ajduković, M. (2011). Risk factors of child physical abuse by parents with mixed anxiety-depressive disorders or posttraumatic stress disorder. Croatian Medical Journal, 52(1), 25-34. https://doi.org/10.3325/ cmj.2011.52.25

Lee, C. Y. S., Anderson, J. R., Horowitz, J. L., \& August, G. J. (2009). Family income and parenting: The role of parental depression and social support. Family Relations, 58(4), 417-430. https:// doi.org/10.1111/j.1741-3729.2009.00563.x

Lee, J. S., \& Lee, K. (2016). Material hardships and social support among Australian families with children. Journal of Child and Family Studies, 25(5), 1539-1549. https://doi.org/10.1007/ s10826-015-0327-z

Mansfield, A. K., Dealy, J. D., \& Keitner, G. I. (2013). Family functioning and income: Does low-income status impact family functioning?. Counseling and Therapy for Couples and Families, 21(3), 297-305. https:/doi. org/10.1177/1066480713476836

McConnell, D., Breitkreuz, R., \& Savage, A. (2010). From financial hardship to child difficulties: Main and moderating effects of perceived social support. Child: Care, Health and Development, 37(5), 679-691. https://doi.org/10.1111/ j.1365-2214.2010.01185.x

Milner, J. S. (1986). The Child Abuse Potential Inventory: Manual (2nd ed.). Webster, NC: Psytec.

Milner, J. S., \& Crouch, J. (2012). Psychometric characteristics of translated versions of the Child Abuse Potential Inventory. Psychology of Violence, 2(3), 239-259. https://doi.org/10.1037/ a0026957

Mistry, R. S., Biesanz, J. C., Taylor, L. C., Burchinal, M., \& Cox, M. J. (2004). Family income and its 
relation to preschool children's adjustment for families in the NICHD Study of Early Child Care. Developmental psychology, 40(5), 727745. https://doi.org/10.1037/0012-1649.40.5.727

Mistry, R. S., Lowe, E. D., Benner, A. D., \& Chien, N. (2008). Expanding the family economic stress model: Insights from a mixed methods approach. Journal of Marriage and Family, 70(1), 196-209. https://doi.org/10.1111/j.17413737.2007.00471.x

Noble, K. G., Houston, S. M., Brito, N. H., Bartsch, H., Kan, E., \& Sowell, E. R. (2015). Family income, parental education and brain structure in children and adolescents. Nature Neuroscience, 18(5), 773-778. https://doi.org/10.1038/nn.3983

Noller, P. (1988). ICPS family functioning scales. St Lucia: University of Queensland.

Pećnik, N. (2003). Inventar rizičnosti za zlostavljanje djeteta: Prikaz instrumenta i njegove validacije u Hrvatskoj. Ljetopis Socijalnog Rada, 10(2), 211-228. https://hrcak.srce.hr/3513

Raikes, A., \& Thompson, R. A. (2005). Efficacy and social support as predictors of parenting stress among families in poverty. Infant Mental Health Journal, 26(3), 177-190. https://doi.org/10.1002/ imhj.20044_

Rajhvajn Bulat, L. Ajduković, M., \& Sušac, N. (2016). Upitnik učinka financijskih poteškoća na odnose u obitelji. Neobjavljeni materijal.

Rajter, M. (2013). Obiteljski stresori i obilježja obitelji kao prediktori roditeljskog nasilja nad djecom (doktorska disertacija). Sveučilište u Zagrebu, Pravni fakultet.

Raboteg-Šarić, Z., \& Pećnik, N. (2006) Bračni status, financijske poteškoće i socijalna podrška kao odrednice roditeljske depresivnosti i odgojnih postupaka. Društvena istraživanja, 15(6), 961985. https://hrcak.srce.hr/18343

Rimac, I., Ogresta, J., \& Ružojčić, M. (2017). Odrednice psihosocijalnih ishoda mladih koji su odrastali u siromaštvu. U L. Arambašić, I. Erceg \& Ž. Kamenov (ur.), 23. Dani Ramira i Zorana Bujasa - Knjiga sažetaka (str. 184-184). Zagreb: Medicinska naklada.

Sethi, D., Bellis, M., Hughes, K., Gilbert, R., Mitis, F., \& Galea, G. (2013). European Report on preventing child maltreatment. Available at http://www.euro.who.int/__data/assets/pdf_ file/0019/217018/European-Report-on-Preventing-Child-Maltreatment.pdf
Stubbs, P., \& Zrinščak, S. (2014). Ulaganje u djecu - kako nadvladati zamku deprivacije. European Commission. Employment, Social Affairs \& Inclusion, Country report Hrvatska.

Stubbs, P., Ledić, M., Rubil, I., \& Zrinščak, S. (2017). Dječje siromaštvo i strategije nošenja sa siromaštvom kućanstva u Hrvatskoj. Istraživački izvještaj. Zagreb: EIZG, Zaklada ADRIS.

Sušac, N., Ajduković, M., \& Rajhvajn Bulat, L. (2015). Iskustvo nasilja u obitelji i trenutne životne prilike kao prediktori rizičnosti majki za zlostavljanje djece. U P. Zarevski, T. Jurin \& K. Modić Stanke (ur.), 22. Dani Ramira i Zorana Bujasa - Sažeci priopćenja (str. 214-214). Zagreb: Filozofski fakultet.

Sušac, N., Skokandić, L., Rimac, I., \& Družić Ljubotina, O. (2017). Uloga ekonomskih problema i roditeljskih ponašanja u iskazivanju internaliziranih i eksternaliziranih problema kod mladih. U L. Arambašić, I. Erceg \& Ž. Kamenov (ur.), 23. Dani Ramira i Zorana Bujasa - Knjiga sažeta$k a$ (str. 185-185). Zagreb : Medicinska naklada.

Šućur, Z., Kletečki Radović, M., Družić Ljubotina, O., \& Babić, Z. (2015). Siromaštvo i dobrobit djece predškolske dobi u Republici Hrvatskoj. Zagreb: Ured UNICEF-a za Hrvatsku.

Tucker, M. C., \& Rodriguez, C. M. (2014). Family dysfunction and social isolation as moderators between stress and child physical abuse risk. Journal of Family Violence, 29(2), 175-186. https:// doi.org/10.1007/s10896-013-9567-0

Vučković Juroš, T., \& Tokić Milaković, A. (2016). Is there a way out? Cultural capital and educational outcomes of young people who grew up in poverty. The Futures We Want: Global Sociology and the Struggles for a Better World. 3rd ISA Forum of Sociology, Vienna, Austria.

World Health Organization. (2016). INSPIRE: Seven strategies for ending violence against children. Geneva: WHO Press.

Zakon o doplatku za djecu. Narodne novine, br. 94/2001, 138/2006, 107/2007, 37/2008, 61/2011, 112/2012, 82/2015, 58/2018.

Zimet, G. D., Dahlem, N. W., Zimet, S. G., \& Farley, G. K. (1988). The multidimensional scale of perceived social support. Journal of Personality Assessment, 52(1), 30-41. https://doi.org/10.1207/ s15327752jpa5201_2 


\title{
Summary
}

\section{FAMILY RELATIONS AND PARENTHOOD IN FAMILIES WITH DIFFERENT INCOME: HOW IS LIFE IN HIGH RISK OF POVERTY CONNECTED TO FAMILY FUNCTIONING OF FAMILIES WITH ADOLESCENTS?}

\author{
Marina Ajduković \\ Department of Social Work, Faculty of Law, University of Zagreb \\ Zagreb, Croatia \\ Miroslav Rajter \\ Research Office, University of Zagreb \\ Zagreb Croatia \\ Ines Rezo \\ Department of Social Work, Faculty of Law, University of Zagreb \\ Zagreb, Croatia
}

The paper assesses the contribution of objective and subjective indicators of socioeconomic status, exposure to stressful events and the availability of social support in prediction of quality of family relationships and the risk of child abuse in mothers of adolescents in families exposed to high and low risk of poverty. The sample included 392 mothers of adolescents attending $1^{\text {st }}$ grade of high school. The criterion for family classification in high and low poverty risk group corresponded with the census for receiving a child benefit ( $N=163$, high risk of poverty, average income per household member $719.14 \mathrm{HRK})$ compared to families who are not entitled to child benefit $(N=229$, low risk of poverty, average income per household member 3,357.53 kunas). The results showed that, according to Conger's Family Stress Model, in families at high risk of poverty, family conflict (measured by the Family Functioning Scale, Noller, 1988) and the risk of child abuse in mothers (measured by the Child Abuse Potential Inventory; Milner 1986) were significantly higher in comparison to low-risk families. For mothers living at high risk of poverty significant predictors for the risk of child abuse are higher level of shame due to the financial situation and exposure to more stressful events. Social support significantly reduces the risk of child abuse for mothers living at high risk of poverty, although it has considerably lower power as a protection factor than it has for the mothers living at low risk of poverty. The finding that $8.7 \%$ of mothers at low risk of poverty and $20.2 \%$ of mothers at high risk of poverty are highly in risk of child abuse is analysed in the context of different socioeconomic predictors and the possibility of an effective integrated approach to families with children at high risk of poverty.

Key words: poverty, quality of family relationships, risk of child abuse. 